\title{
Endo-Selective Iron Catalysts for Intramolecular Alkyne Hydrofunctionalization
}

\author{
Supporting Information \\ Benjamin J. Bridge, Paul D. Boyle, and Johanna M. Blacquiere* \\ Department of Chemistry \\ University of Western Ontario \\ London, Ontario, Canada, N6A 5B7
}

Table of Contents

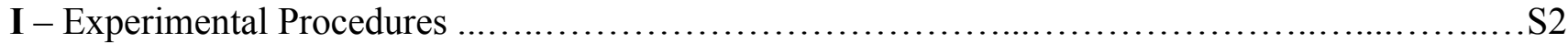

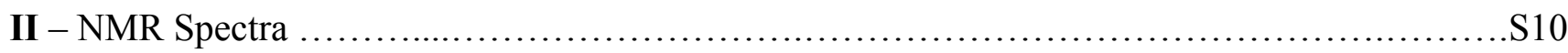

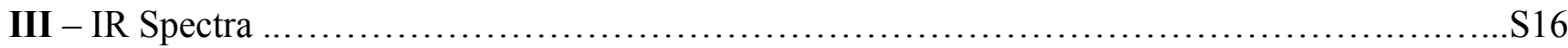

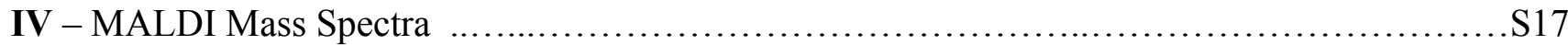

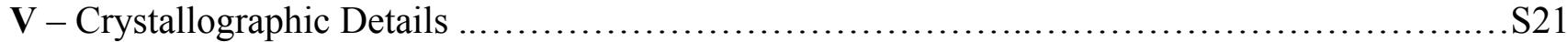

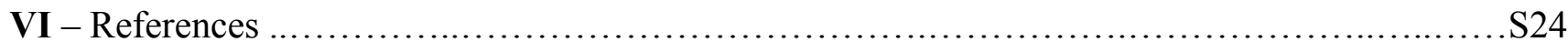




\section{I - Experimental Procedures}

\section{General Experimental Considerations}

Air- and water-sensitive reactions were performed under Ar or $\mathrm{N}_{2}$ using standard Schlenk line or glovebox techniques and all glassware was oven dried at $150{ }^{\circ} \mathrm{C}$ prior to use. Pyrene (98\%), 2ethynylaniline (98\%), tetralin (1,2,3,4-tetrahydronaphthalene; 99\%), $\mathrm{FeCl}_{2}$ (98\%), lithium pentamethylcyclopentadienide, potassium hexafluorophosphate $(>99 \%)$, and 2-methyltetrahydrofuran (Me-THF; >99\% anhydrous) were obtained from Sigma-Aldrich. $\mathrm{CyPH}_{2}(97 \%)$ and $\mathrm{PhPH}_{2}(99 \%)$ were obtained from Strem Chemicals. Dichloromethane- $d_{2}(99.8 \%)$ was obtained from Cambridge Isotope Laboratories. 1,5-Diaza-3,7-diphosphacyclooctane $\left(\mathrm{P}_{2}^{\mathrm{R}} \mathrm{N}^{\mathrm{Ph}}{ }_{2}\right)$ ligands were synthesized following a modified literature procedure that used $37 \% \mathrm{w} / \mathrm{w}$ aqueous paraformaldehyde solution in place of solid paraformaldehyde. ${ }^{1}$ The ${ }^{1} \mathrm{H}$ and ${ }^{31} \mathrm{P}\left\{{ }^{1} \mathrm{H}\right\}$ spectra for the $\mathrm{P}^{\mathrm{Ph}}{ }_{2} \mathrm{~N}^{\mathrm{Ph}}$ and $\mathrm{P}^{\mathrm{Cy}}{ }_{2} \mathrm{~N}^{\mathrm{Ph}}$ ligands matched reported characterization data. ${ }^{2-3}\left[\mathrm{Fe}\left(\mathrm{Cp}^{*}\right)(\mathrm{MeCN})_{3}\right] \mathrm{PF}_{6}$ was synthesized following a literature procedure. ${ }^{4}$ Authentic 1-methylene-1,3-dihydroisobenzofuran was synthesized via $t$-BuOK catalysed cyclization of EBA in DMSO following a literature procedure. ${ }^{5}$ Dried and degassed tetrahydrofuran, diethyl ether, dichloromethane, pentane and acetonitrile were obtained from an Innovative Technology 400-5 Solvent Purification System and stored in a glovebox under $\mathrm{N}_{2}$ over 4 $\AA$ molecular sieves with the exception of acetonitrile, which was stored over $3 \AA$ molecular sieves (Fluka and activated at $150{ }^{\circ} \mathrm{C}$ for over $12 \mathrm{~h}$ ). Ethanol and aniline were degassed by bubbling with $\mathrm{N}_{2}$, and 1,2-dichloroethane (DCE) was degassed by bubbling with $\mathrm{N}_{2}$ after drying over $4 \AA$ molecular sieves. Dichloromethane- $d_{2}$ was dried with $4 \AA$ molecular sieves. All other chemicals were used as received.

Charge-transfer Matrix Assisted Laser Desorption/Ionization (MALDI) mass spectra were collected on an $\mathrm{AB}$ Sciex $5800 \mathrm{TOF} / \mathrm{TOF}$ mass spectrometer using a pyrene matrix in a 10:1 molar ratio to metal complex. Samples were spotted on the target plate from solutions in DCM. All NMR spectra were recorded on either an Inova $600 \mathrm{MHz}$ or Bruker $400 \mathrm{MHz}$ instrument. ${ }^{1} \mathrm{H}$ and ${ }^{13} \mathrm{C}\left\{{ }^{1} \mathrm{H}\right\}$ spectra acquired in DCM- $d_{2}$ were referenced internally against the residual solvent signal (DCM at $5.32 \mathrm{ppm}$ ) to TMS at 0 ppm. ${ }^{31} \mathrm{P}\left\{{ }^{1} \mathrm{H}\right\}$ spectra were referenced externally to $85 \%$ phosphoric acid at $0.00 \mathrm{ppm}$. Multiplicities are described as s (singlet), d (doublet), $\mathrm{t}$ (triplet), and sept (septet). X-ray diffraction measurements were made on a Bruker Kappa Axis Apex2 diffractometer at a temperature of $110 \mathrm{~K}$. Infrared spectra were collected on solid samples using a Bruker ALPHA II FTIR spectrometer. Quantification of catalytic reactivity was achieved using an Agilent 7890a gas chromatography with a flame ionization detector (GC-FID), fitted with a HP-5 column. Calibration curves of 2-ethynylaniline 
(EA) and indole (Ind) were prepared. The response factor for Ind with respect to EA was 1.06 and this value was applied to quantify in situ yields of Ind. Contamination by anisole and minor decomposition products prevented the acquisition of accurate calibration curves for isochromene (IC). To quantify the in situ yields of IC, response factor of 1 with respect to 2-ethynylbenzyl alcohol was assumed.

\section{Synthesis of $\left[\mathrm{Fe}\left(\mathrm{Cp}^{*}\right)\left(\mathrm{P}^{\mathrm{R}}{ }_{2} \mathrm{~N}^{\mathrm{Ph}}{ }_{2}\right)(\mathrm{MeCN})\right] \mathrm{PF}_{6}$ Complexes}

General Procedure: Complexes of the type $\left[\mathrm{Fe}\left(\mathrm{Cp}^{*}\right)\left(\mathrm{P}_{2}^{\mathrm{R}}{ }_{2} \mathrm{~N}_{2}{ }_{2}\right)(\mathrm{MeCN})\right] \mathrm{PF}_{6}$ were synthesized according to an adapted literature procedure ${ }^{6}$ and performed in a glovebox under $\mathrm{N}_{2}$ atmosphere. To a $20 \mathrm{~mL}$ vial with a stir bar, the $\mathrm{P}_{2}^{\mathrm{R}} \mathrm{N}^{\mathrm{Ph}}$ ligand (0.50 mmol, 1.0 equiv.) and $\mathrm{FeCl}_{2}$ (76 mg, $0.60 \mathrm{mmol}$, 1.2 equiv.) were added followed by THF $(8 \mathrm{~mL})$. The reaction was stirred at room temperature for $1 \mathrm{~h}$ until a clear solution was obtained. LiCp* (85 mg, $0.60 \mathrm{mmol}, 1.2$ equiv.) was added as a suspension in THF (4 mL) and the solution was stirred for 5 minutes. $\mathrm{KPF}_{6}(110 \mathrm{mg}, 0.60 \mathrm{mmol}, 1.2$ equiv.) was added and the reaction was stirred for 5 minutes before acetonitrile $(5 \mathrm{~mL})$ was added. The reaction was stirred for an additional $2 \mathrm{~h}$, during which an orange suspension had formed. The solvent was removed under reduced pressure and the solids were taken up in acetonitrile $(5 \mathrm{~mL})$ then filtered through a glass microfiber plug. The plug was washed with acetonitrile until the washings were clear. The solvent of the filtrate was removed under vacuum and the remaining solids were taken up in DCM $(5 \mathrm{~mL})$ and filtered through Celite, which was washed with DCM. The filtrate solvent was removed under vacuum and the remaining solids were washed with $\mathrm{Et}_{2} \mathrm{O}(3 \times 7 \mathrm{~mL})$. The remaining solids were dried under vacuum.

$\left[\mathbf{F e}\left(\mathbf{C p}^{*}\right)\left(\mathbf{P}^{\mathrm{Cy}}{ }_{2} \mathbf{N}^{\mathbf{P h}}{ }_{2}\right)\left(\mathbf{M e C N}_{\mathbf{2}}\right] \mathbf{P F}_{6}\right.$ (1a): Yield: 86\% (363 mg, $\left.0.43 \mathrm{mmol}\right)$, red solid. ${ }^{1} \mathrm{H}(400 \mathrm{MHz}$, $\left.\mathrm{CD}_{2} \mathrm{Cl}_{2}\right) \delta:$ 7.33-7.27 (m, Ph-H, 4H), 7.07 (d, $\left.{ }^{3} J=8.3 \mathrm{~Hz}, \mathrm{Ph}-H, 2 \mathrm{H}\right), 7.01-6.96$ (m, Ph- H, 3H), 6.94 $\left(\mathrm{t},{ }^{3} \mathrm{~J}=7.3 \mathrm{~Hz}, \mathrm{Ph}-\mathrm{H}, 1 \mathrm{H}\right), 3.90-3.82$ (m, P-CH$\left.-\mathrm{N}, 2 \mathrm{H}\right), 3.80-3.72\left(\mathrm{~m}, \mathrm{P}-\mathrm{CH}_{2}-\mathrm{N}, 2 \mathrm{H}\right), 3.23-3.17$ (m, P-CH $\left.H_{2}-\mathrm{N}, 2 \mathrm{H}\right), 2.83-2.74$ (m, P-CH $\left.\mathrm{CH}_{2} \mathrm{~N}, 2 \mathrm{H}\right), 2.70-2.61$ (m, P-CH, 2H), 2.39 (s, Fe-NCCH 3 , 3H), 2.17$2.08\left(\mathrm{~m}, \mathrm{CH}_{2}, 4 \mathrm{H}\right), 2.05-1.97\left(\mathrm{~m}, \mathrm{CH}_{2}, 4 \mathrm{H}\right), 1.91-1.84\left(\mathrm{~m}, \mathrm{CH}_{2}, 2 \mathrm{H}\right), 1.68-1.59\left(\mathrm{~m}, \mathrm{CH}_{2}, 2 \mathrm{H}\right), 1.64(\mathrm{~s}$, $\left.\mathrm{C}_{5}\left(\mathrm{CH}_{3}\right)_{5}, 15 \mathrm{H}\right), 1.59-1.44\left(\mathrm{~m}, \mathrm{CH}_{2}, 4 \mathrm{H}\right), 1.40-1.31\left(\mathrm{~m}, \mathrm{CH}_{2}, 2 \mathrm{H}\right), 1.21-1.11\left(\mathrm{~m}, \mathrm{CH}_{2}, 2 \mathrm{H}\right) .{ }^{31} \mathrm{P}\left\{{ }^{1} \mathrm{H}\right\}$ $\left(162 \mathrm{MHz}, \mathrm{CD}_{2} \mathrm{Cl}_{2}\right) \delta: 52.4\left(\mathrm{~s}, P_{C y}\right),-144.5$ (sept, $\left.{ }^{1} J_{\mathrm{P}-\mathrm{F}}=711.1 \mathrm{~Hz}, P \mathrm{~F}_{6}\right) .{ }^{13} \mathrm{C}\left\{{ }^{1} \mathrm{H}\right\}(101 \mathrm{MHz}$, $\left.\mathrm{CD}_{2} \mathrm{Cl}_{2}\right) \delta: 153.6\left(\mathrm{t},{ }^{3} J_{\mathrm{C}-\mathrm{P}}=7.0 \mathrm{~Hz}, \mathrm{~N}-C_{A r}\right), 152.3\left(\mathrm{t},{ }^{3} J_{\mathrm{C}-\mathrm{P}}=9.8 \mathrm{~Hz}, \mathrm{~N} C_{A r}\right), 132.6\left(\mathrm{~s}, C_{A r}\right), 129.89(\mathrm{~s}$, $\left.C_{A r}\right), 129.86\left(\mathrm{~s}, \mathrm{Fe}-\mathrm{NCCH}_{3}\right), 122.6\left(\mathrm{~s}, C_{A r}\right), 121.4\left(\mathrm{~s}, C_{A r}\right), 119.0\left(\mathrm{~s}, C_{A r}\right), 116.9\left(\mathrm{~s}, C_{A r}\right), 88.3(\mathrm{~s}$, $\left.C_{5}\left(\mathrm{CH}_{3}\right)_{5}\right), 46.0\left(\mathrm{ABX}, \mathrm{P}-\mathrm{CH}_{2}-\mathrm{N}\right), 45.3\left(\mathrm{ABX}, \mathrm{P}-\mathrm{CH}_{2} \mathrm{~N}\right), 39.8\left(\mathrm{ABX}, \mathrm{P}-\mathrm{CH}_{C y}\right), 28.3\left(\mathrm{~s}, \mathrm{CH}_{2}\right), 27.6(\mathrm{~s}$, $\left.\mathrm{CH}_{2}\right), 27.6\left(\mathrm{ABX}, \mathrm{P}-\mathrm{CH}-\mathrm{CH}_{2}\right), 27.3\left(\mathrm{ABX}, \mathrm{P}-\mathrm{CH}-\mathrm{CH}_{2}\right), 26.5\left(\mathrm{~s}, \mathrm{CH}_{2}\right), 10.3\left(\mathrm{~s}, \mathrm{C}_{5}\left(\mathrm{CH}_{3}\right)_{5}\right), 5.4(\mathrm{~s}, \mathrm{Fe}-$ $\left.\mathrm{NCCH}_{3}\right)$. MALDI MS (pyrene matrix): Calc. $m / z 657.3\left[\mathrm{Fe}\left(\mathrm{Cp}^{*}\right)\left(\mathrm{P}^{\mathrm{Cy}}{ }_{2} \mathrm{~N}^{\mathrm{Ph}}{ }_{2}\right]^{+}\right.$, Obs. $m / z$ 657.4. ATR- 
FTIR $\left(\mathrm{cm}^{-1}\right): v 1594(\mathrm{C}=\mathrm{C})$ (phenyl ring). Crystals suitable for X-Ray diffraction were grown by dissolving complex 1a in DCM and layering the solution with pentane.

$\left[\mathbf{F e}(\mathbf{C p} *)\left(\mathbf{P}^{\mathrm{Ph}}{ }_{2} \mathbf{N}^{\mathbf{P h}}{ }_{2}\right)(\mathbf{M e C N})\right] \mathbf{P F}_{6}(\mathbf{1 b})$ : Yield: 85\% (358 mg, $\left.0.43 \mathrm{mmol}\right)$, red solid. ${ }^{1} \mathrm{H}(400 \mathrm{MHz}$, $\left.\mathrm{CD}_{2} \mathrm{Cl}_{2}\right) \delta$ : 7.72-7.60 (m, Ph- $\left.H, 10 \mathrm{H}\right), 7.45-7.39$ (m, Ph- $\left.H, 2 \mathrm{H}\right)$, 7.32-7.26 (m, Ph- H, 2H), 7.23-7.15 (m, Ph-H, 2H), 7.06 (t, $\left.{ }^{3} J=7.3 \mathrm{~Hz}, \mathrm{Ph}-H, 1 \mathrm{H}\right), 6.89-6.82$ (m, Ph- H, 3H), 4.46-4.32 (m, P-CH $-\mathrm{N}$, 2H), 3.93-3.82 (m, P-CH $\left.H_{2}-\mathrm{N}, 2 \mathrm{H}\right), 3.81-3.65$ (m, P-CH$\left.-\mathrm{N}, 2 \mathrm{H}\right), 3.60-3.48\left(\mathrm{~m}, \mathrm{P}-\mathrm{CH}_{2}-\mathrm{N}, 2 \mathrm{H}\right), 2.44$ (s, $\left.\mathrm{Fe}-\mathrm{NCCH}_{3}, 3 \mathrm{H}\right), 1.22\left(\mathrm{~s}, \mathrm{C}_{5}\left(\mathrm{CH}_{3}\right)_{5}, 15 \mathrm{H}\right) .{ }^{31} \mathrm{P}\left\{{ }^{1} \mathrm{H}\right\}\left(162 \mathrm{MHz}, \mathrm{CD}_{2} \mathrm{Cl}_{2}\right) \delta: 50.2\left(\mathrm{~s}, P_{P h}\right),-144.7$ (sept, $\left.{ }^{1} J_{\mathrm{P}-\mathrm{F}}=710.6 \mathrm{~Hz}, P \mathrm{~F}_{6}\right) .{ }^{13} \mathrm{C}\left\{{ }^{1} \mathrm{H}\right\}\left(101 \mathrm{MHz}, \mathrm{CD}_{2} \mathrm{Cl}_{2}\right) \delta: 152.8\left(\mathrm{t},{ }^{3} J_{\mathrm{C}-\mathrm{P}}=9.9 \mathrm{~Hz}, \mathrm{~N}-C_{A r}\right), 151.7\left(\mathrm{t},{ }^{3} J_{\mathrm{C}-\mathrm{P}}\right.$ $\left.=7.3 \mathrm{~Hz}, \mathrm{~N}-C_{A r}\right), 132.7\left(\mathrm{~s}, C_{A r}\right), 132.5\left(\mathrm{ABX}, \mathrm{P}-C_{A r}\right), 131.4\left(\mathrm{~s}, \mathrm{Fe}-\mathrm{NCCH}_{3}\right), 130.5\left(\mathrm{ABX}, \mathrm{P}-C_{A r}\right)$, $130.2\left(\mathrm{ABX}, \mathrm{P}-C_{A r}\right), 130.1\left(\mathrm{~s}, C_{A r}\right), 129.8\left(\mathrm{~s}, C_{A r}\right), 122.3\left(\mathrm{~s}, C_{A r}\right), 121.8\left(\mathrm{~s}, C_{A r}\right), 118.1\left(\mathrm{~s}, C_{A r}\right), 117.7$ $\left(\mathrm{s}, C_{A r}\right), 89.5\left(\mathrm{~s}, C_{5}\left(\mathrm{CH}_{3}\right)_{5}\right), 53.5\left(\mathrm{ABX}, \mathrm{P}-\mathrm{CH}_{2}-\mathrm{N}\right), 46.9\left(\mathrm{ABX}, \mathrm{P}-\mathrm{CH}_{2}-\mathrm{N}\right), 9.7\left(\mathrm{~s}, \mathrm{C}_{5}\left(\mathrm{CH}_{3}\right)_{5}\right), 5.5(\mathrm{~s}$, Fe-NCCH$H_{3}$ ). MALDI MS (pyrene matrix): Calc. $m / z 645.2\left[\mathrm{Fe}\left(\mathrm{Cp}^{*}\right)\left(\mathrm{P}^{\mathrm{Ph}}{ }_{2} \mathrm{~N}^{\mathrm{Ph}}{ }_{2}\right)\right]^{+}, \mathrm{Obs} . m / z$ 645.2. ATR-FTIR $\left(\mathrm{cm}^{-1}\right): v 1595(\mathrm{C}=\mathrm{C}$, phenyl ring).

\section{Synthesis of $\left[\mathrm{Fe}\left(\mathrm{Cp}{ }^{*}\right)\left(\mathrm{P}^{\mathrm{Cy}}{ }_{2} \mathrm{~N}^{\mathrm{Ph}}{ }_{2}\right)(\mathrm{C}=\mathrm{CHPh})\right] \mathrm{PF}_{6}(2 \mathrm{a})$}

In a glovebox under $\mathrm{N}_{2}$ atmosphere, complex 1a (19 mg, $0.021 \mathrm{mmol}, 1$ equiv) was added to a $4 \mathrm{~mL}$ screw cap vial containing a stir bar. A solution of phenylacetylene ( $24 \mathrm{mg}, 0.23 \mathrm{mmol}, 11 \mathrm{equiv}$.) in DCE $(1 \mathrm{~mL})$ was added to the vial, which was capped and sealed with tape. The vial was removed from the glovebox and heated to $70{ }^{\circ} \mathrm{C}$ for 2 hours in an oil bath. The reaction vial was taken back into the glovebox and the solvent was removed under vacuum. The resulting solids were washed with $\mathrm{Et}_{2} \mathrm{O}(3 \times 3 \mathrm{~mL})$ and dried under vacuum to afford $\mathbf{2 a}$ as an orange solid. Yield: $17 \mathrm{mg}, 85 \% .{ }^{1} \mathrm{H}(400$ $\mathrm{MHz}, \mathrm{CD}_{2} \mathrm{Cl}_{2}$ ) $\delta:$ 7.44-7.36 (m, Ph-H, 2H), 7.34-7.26 (m, Ph-H, 4H), 7.22-7.11 (m, Ph-H, 5H), 7.097.00 (m, Ph-H, 2H), 6.98-6.90 (m, Ph- H, 2H), 6.01 (s, C=CHPh, 1H), 4.02-3.91 (m, P-CH2-N, 2H), 3.71-3.60 (m, P-CH2 $-\mathrm{N}, 2 \mathrm{H}), 3.55-3.45$ (m, P-CH $-\mathrm{N}, 2 \mathrm{H}), 3.37-3.27$ (m, P-CH $-\mathrm{N}, 2 \mathrm{H}), 2.13-1.75$ (m, $\left.\mathrm{CH}_{2}, 10 \mathrm{H}\right), 1.86\left(\mathrm{~s}, \mathrm{C}_{5}\left(\mathrm{CH}_{3}\right)_{5}, 15 \mathrm{H}\right), 1.72-1.60$ (m, P-CH, $\left.2 \mathrm{H}\right), 1.54-1.38\left(\mathrm{~m}, \mathrm{CH}_{2}, 4 \mathrm{H}\right), 1.34-1.19$ (m, $\left.\mathrm{CH}_{2}, 4 \mathrm{H}\right), 0.96-0.81\left(\mathrm{~m}, \mathrm{CH}_{2}, 2 \mathrm{H}\right) .{ }^{31} \mathrm{P}\left\{{ }^{1} \mathrm{H}\right\}\left(162 \mathrm{MHz}, \mathrm{CD}_{2} \mathrm{Cl}_{2}\right) \delta: 51.1\left(\mathrm{~s}, P_{C y}\right),-144.5\left(\mathrm{sept},{ }^{1} J_{\mathrm{P}-}\right.$ $\left.\mathrm{F}=710.6 \mathrm{~Hz}, P \mathrm{~F}_{6}\right) \cdot{ }^{13} \mathrm{C}\left\{{ }^{1} \mathrm{H}\right\}\left(101 \mathrm{MHz}, \mathrm{CD}_{2} \mathrm{Cl}_{2}\right) \delta: 359.6\left(\mathrm{Fe}=\mathrm{C}=\mathrm{CHPh}\right.$, assigned by $\left.{ }^{1} \mathrm{H}-{ }^{13} \mathrm{C} \mathrm{HMBC}\right)$, $153.1\left(\mathrm{t},{ }^{3} J_{\mathrm{C}-\mathrm{P}}=8.4 \mathrm{~Hz}, \mathrm{~N}-C_{A r}\right), 151.4\left(\mathrm{t},{ }^{3} J_{\mathrm{C}-\mathrm{P}}=10.1 \mathrm{~Hz}, \mathrm{~N} C_{A r}\right), 130.6\left(\mathrm{~s}, C_{A r}\right), 130.2\left(\mathrm{~s}, C_{A r}\right), 130.1$ $\left(\mathrm{s}, C_{A r}\right), 129.2\left(\mathrm{~s}, C_{A r}\right), 127.2\left(\mathrm{~s}, C_{A r}\right), 126.9\left(\mathrm{~s}, C_{A r}\right), 125.7(\mathrm{~s}, \mathrm{Fe}=\mathrm{C}=C \mathrm{HPh}), 123.6\left(\mathrm{~s}, C_{A r}\right), 122.6(\mathrm{~s}$, $\left.C_{A r}\right), 119.6\left(\mathrm{~s}, C_{A r}\right), 117.4\left(\mathrm{~s}, C_{A r}\right), 100.8\left(\mathrm{~s}, C_{5}\left(\mathrm{CH}_{3}\right)_{5}\right), 46.7\left(\mathrm{ABX}, \mathrm{P}-C_{2}-\mathrm{N}\right), 46.2\left(\mathrm{ABX}, \mathrm{PCH} \mathrm{H}_{2} \mathrm{~N}\right)$, $38.7\left(\mathrm{ABX}, \mathrm{PCH}_{C y}\right), 28.8\left(\mathrm{~s}, \mathrm{CH}_{2}\right), 27.6\left(\mathrm{ABX}, \mathrm{PCHCH}{ }_{2}\right), 27.4\left(\mathrm{ABX}, \mathrm{PCHCH}{ }_{2}\right), 27.0\left(\mathrm{~s}, \mathrm{CH}_{2}\right), 26.0$ $\left(\mathrm{s}, \quad \mathrm{CH}_{2}\right), \quad 10.7 \quad\left(\mathrm{~s}, \quad \mathrm{C}_{5}\left(\mathrm{CH}_{3}\right)_{5}\right)$. MALDI $\mathrm{MS}$ (pyrene matrix): Calc. $\mathrm{m} / \mathrm{z} \quad 759.4$ 
$\left[\mathrm{Fe}\left(\mathrm{Cp}^{*}\right)\left(\mathrm{P}^{\mathrm{Cy}}{ }_{2} \mathrm{~N}^{\mathrm{Ph}}\right)(\mathrm{C}=\mathrm{CHPh})\right]^{+}$, Obs. $\mathrm{m} / z$ 759.4. ATR-FTIR $\left(\mathrm{cm}^{-1}\right): v 1617(\mathrm{C}=\mathrm{C})$ (vinylidene), 1596 $(\mathrm{C}=\mathrm{C})$ (phenyl ring).

\section{General Procedure for the Catalytic Cyclization of Substrates}

In a glovebox, stock solutions of substrate (2-ethynylaniline or 2-ethynylbenzyl alcohol, $600 \mathrm{mM}$ ) and internal standard (tetralin, $400 \mathrm{mM}$ ) were prepared in either DCM, DCE, Me-THF, or anisole and combined in equivalent volumes to give one stock solution with $300 \mathrm{mM}$ substrate and $200 \mathrm{mM}$ internal standard. Catalyst (1a or 1b) was added as a solution in $\operatorname{DCM}(25,50$, or $100 \mu \mathrm{L}$ of $15 \mathrm{mM})$ to $4 \mathrm{~mL}$ vials containing stir bars and the solvent was allowed to evaporate. The amount of catalyst solution added was varied depending on the desired loading for the trial $(0.5,1.0$, or $2.0 \mathrm{~mol} \%)$. The vials were then charged with the substrate/internal standard stock solution $(250 \mu \mathrm{L})$ and additional solvent (250 $\mu \mathrm{L}$ DCM, DCE, MeTHF, or anisole), giving a final volume of $500 \mu \mathrm{L}$. The final concentrations for all vials was $150 \mathrm{mM}$ in substrate, $100 \mathrm{mM}$ in internal standard, and $0.75,1.5$, or $3.0 \mathrm{mM}$ in catalyst. A final vial was charged with substrate/internal standard stock solution $(250 \mu \mathrm{L})$ for use as the time $=0$ sample. The vials were capped and removed from the glovebox and heated with stirring to various temperatures $\left(40-110{ }^{\circ} \mathrm{C}\right)$. After each desired time, 2 vials were removed from heat and a $20 \mu \mathrm{L}$ aliquot was immediately diluted to $3 \mathrm{mM}$ (based on substrate) in acetonitrile (980 $\mu \mathrm{L}$ ) and analyzed by GC-FID. A $10 \mu \mathrm{L}$ aliquot of the T0 sample was diluted with acetonitrile (990 $\mu \mathrm{L})$ and analyzed by GC-FID.

\section{Catalysis Control Reactions}

$\mathrm{FeCl}_{2}$ and $\mathrm{FeCl}_{2}+\mathrm{P}^{\mathrm{Cy}}{ }_{2} \mathrm{~N}^{\mathrm{Ph}}{ }_{2}$ as Catalysts

$\mathrm{FeCl}_{2}(19 \mathrm{mg}, 0.15 \mathrm{mmol})$ was dissolved in THF $(9.73 \mathrm{~mL})$ and stirred overnight until a clear colourless solution was obtained. A portion of this $\mathrm{FeCl}_{2} / \mathrm{THF}$ stock solution $(1.543 \mathrm{~mL})$ was added to the $\mathrm{P}^{\mathrm{Cy}}{ }_{2} \mathrm{~N}^{\mathrm{Ph}}{ }_{2}$ ligand (11 mg, $\left.0.024 \mathrm{mmol}\right)$ and stirred until a clear yellow solution was obtained. Each of the $\mathrm{FeCl}_{2}$ and $\mathrm{FeCl}_{2}+\mathrm{P}^{\mathrm{Cy}}{ }_{2} \mathrm{~N}^{\mathrm{Ph}}{ }_{2}$ stock solutions (50 $\mu \mathrm{L}$ of $15 \mathrm{mM}$ for $1.0 \mathrm{~mol} \%$ ) were used in place of the catalyst stock solution in the general procedure for catalytic cyclization of substrates and analyzed after 1 hour reaction time by GC-FID.

\section{1,4-Cyclohexadiene as a Radical Trap}

A 1,4-cyclohexadiene stock solution $(0.76 \mu \mathrm{M})$ in anisole was used in the general procedure for catalytic cyclization of substrates in place of the additional solvent $(250 \mu \mathrm{L})$ needed to reach the 
desired total volume of $500 \mu \mathrm{L}$. Complex 1a $(25 \mu \mathrm{L}$ of $15 \mathrm{mM}$ for $0.5 \mathrm{~mol} \%)$ was used as the catalyst in a 2:1 ratio with respect to cyclohexadiene and the reactions were analyzed after $1 \mathrm{~h}$ reaction time by GC-FID.

\section{Dark Reaction}

Dark reactions were performed according to the general procedure for catalytic cyclization of substrates using complex 1a ( $25 \mu \mathrm{L}$ of $15 \mathrm{mM}$ for $0.5 \mathrm{~mol} \%$ ) with vials wrapped in aluminium foil prior to and during heating. Reaction aliquots were analyzed after 1 hour reaction times by GC-FID.

\section{Non-Catalytic Control Reaction}

In a glovebox, stock solutions of substrate (2-ethynylaniline and indole, $600 \mathrm{mM}$ each) and internal standard (tetralin, $400 \mathrm{mM}$ ) were prepared in anisole, combined in equivalent volumes, and diluted with an equivalent volume of anisole to give one stock solution with $150 \mathrm{mM}$ of each substrate and $100 \mathrm{mM}$ internal standard. $4 \mathrm{~mL}$ vials containing stir bars were then charged with the substrate/internal standard stock solution $(500 \mu \mathrm{L})$ and additional solvent ( $250 \mu \mathrm{L}$ anisole), giving a final volume of $500 \mu \mathrm{L}$. The vials were capped and removed from the glovebox and heated with stirring $\left(110{ }^{\circ} \mathrm{C}\right)$. After each desired time, 2 vials were removed from heat and a $20 \mu \mathrm{L}$ aliquot was immediately diluted to $3 \mathrm{mM}$ (based on substrate) in acetonitrile (980 $\mu \mathrm{L})$ and analyzed by GC-FID.

Table S1. Conditions optimization for the cyclization of 2-ethynyl aniline (EA) to indole (Ind) with iron catalysts $\mathbf{1 a}$ and $\mathbf{1 b}{ }^{[\mathrm{a}]}$

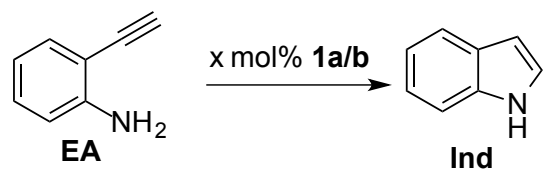

\begin{tabular}{|c|c|c|c|c|c|c|}
\hline Entry & Solvent & Temp. $\left({ }^{\circ} \mathrm{C}\right)$ & {$[\mathrm{Fe}](\mathrm{mol} \%)$} & Time (h) & Conv. $(\%)^{[b]}$ & Ind $(\%)^{[\mathrm{c}]}$ \\
\hline 1 & DCM & 40 & $\mathbf{1 a}(1)$ & 1 & 2 & 0 \\
\hline \multirow{3}{*}{2} & \multirow{3}{*}{$\mathrm{DCE}^{[\mathrm{d}]}$} & \multirow{3}{*}{40} & \multirow{3}{*}{$\mathbf{1 a}(1)$} & 24 & 2 & 0 \\
\hline & & & & 1 & 4 & 2 \\
\hline & & & & 24 & 9 & 7 \\
\hline
\end{tabular}




\begin{tabular}{|c|c|c|c|c|c|c|}
\hline \multirow[t]{2}{*}{3} & Me-THF & 70 & 1a (1) & 1 & 19 & 18 \\
\hline & & & & 24 & 36 & 15 \\
\hline \multirow[t]{2}{*}{4} & anisole & 70 & $\mathbf{1 a}(1)$ & 1 & 15 & 12 \\
\hline & & & & 24 & 33 & 10 \\
\hline \multirow[t]{2}{*}{5} & DCE & 70 & $1 \mathbf{a}(1)$ & 1 & 17 & 17 \\
\hline & & & & 24 & 28 & 14 \\
\hline \multirow[t]{2}{*}{6} & anisole & 110 & $\mathbf{1 a}(1)$ & 1 & 85 & 78 \\
\hline & & & & 24 & 91 & 55 \\
\hline 7 & anisole & 110 & $\mathbf{1 a}(0.5)$ & 1 & 79 & 72 \\
\hline \multirow[t]{2}{*}{8} & anisole & 110 & $1 \mathbf{b}(1)$ & 1 & 99 & 93 \\
\hline & & & & 24 & 94 & 64 \\
\hline \multirow[t]{2}{*}{9} & anisole & 110 & $1 \mathbf{b}(0.5)$ & 1 & 87 & 84 \\
\hline & & & & 24 & 92 & 70 \\
\hline 10 & anisole & 110 & $\mathrm{FeCl}_{2}(1)$ & 1 & 17 & 0 \\
\hline 11 & anisole & 110 & $\begin{array}{l}\mathrm{FeCl}_{2}+ \\
\mathrm{P}^{\mathrm{Cy}}{ }_{2} \mathrm{~N}^{\mathrm{Ph}}{ }_{2}\end{array}$ & 1 & 2 & 0 \\
\hline $12^{[\mathrm{e}]}$ & anisole & 110 & $\mathbf{1 a}(0.5)$ & 1 & 76 & 70 \\
\hline $13^{[\mathrm{f}]}$ & anisole & 110 & $\mathbf{1 a}(0.5)$ & 1 & 76 & 70 \\
\hline
\end{tabular}

[a] Conditions: EA (150 mM), reactions were heated for $1 \mathrm{~h}$ prior to analysis by GC-FID. Tetralin was used as an internal standard, all data is an average of at least two trials, errors were all within $+/-5 \%$. [b] Conversion of EA. [c] In-situ yields determined by calibrated GC-FID. [d] 1,2-dichloroethane. [e] Reaction vessel wrapped in foil to minimize light exposure. [f] 0.5 equiv cyclohexa-1,4-diene was added. 


\section{Catalytic Synthesis of Isochromene}

In a glovebox under an $\mathrm{N}_{2}$ atmosphere, complex $\mathbf{1 b}(19 \mathrm{mg}, 0.023 \mathrm{mmol}, 1$ equiv.) was added to a vial along with 2-ethynylbenzyl alcohol (152 mg, $1.15 \mathrm{mmol}, 50$ equiv.) and anisole (7.66 mL). The solution was added to $4 \mathrm{~mL}$ screw cap vials containing stir bars (500 $\mu \mathrm{L}$ each vial), which were sealed with tape and removed from the glovebox. The vials were heated to $110{ }^{\circ} \mathrm{C}$ for 1 hour with stirring and each was analyzed by GC-FID to confirm consumption of the starting material EBA, and that IC was the only product. The combined solutions were passed through a plug of silica and the plug was rinsed with toluene. The resulting solution was concentrated under vacuum to afford a yellow oil. Yield: $46 \mathrm{mg}(30 \%)$. The removal of the solvent $\left(\mathrm{bp}=154{ }^{\circ} \mathrm{C}\right)$ may have also resulted in product loss (Predicted bp: $\mathbf{I C}=244 \pm 30{ }^{\circ} \mathrm{C}$ at $1 \mathrm{~atm} ; 1$-methylene-1,3-dihydroisobenzofuran $=244 \pm 30{ }^{\circ} \mathrm{C}$ at 1 atm). The ${ }^{1} \mathrm{H}$ NMR spectrum of the oil is shown below in Figures $\mathrm{S} 1$ and S2. The signals are consistent with the literature values for IC. $^{7}$

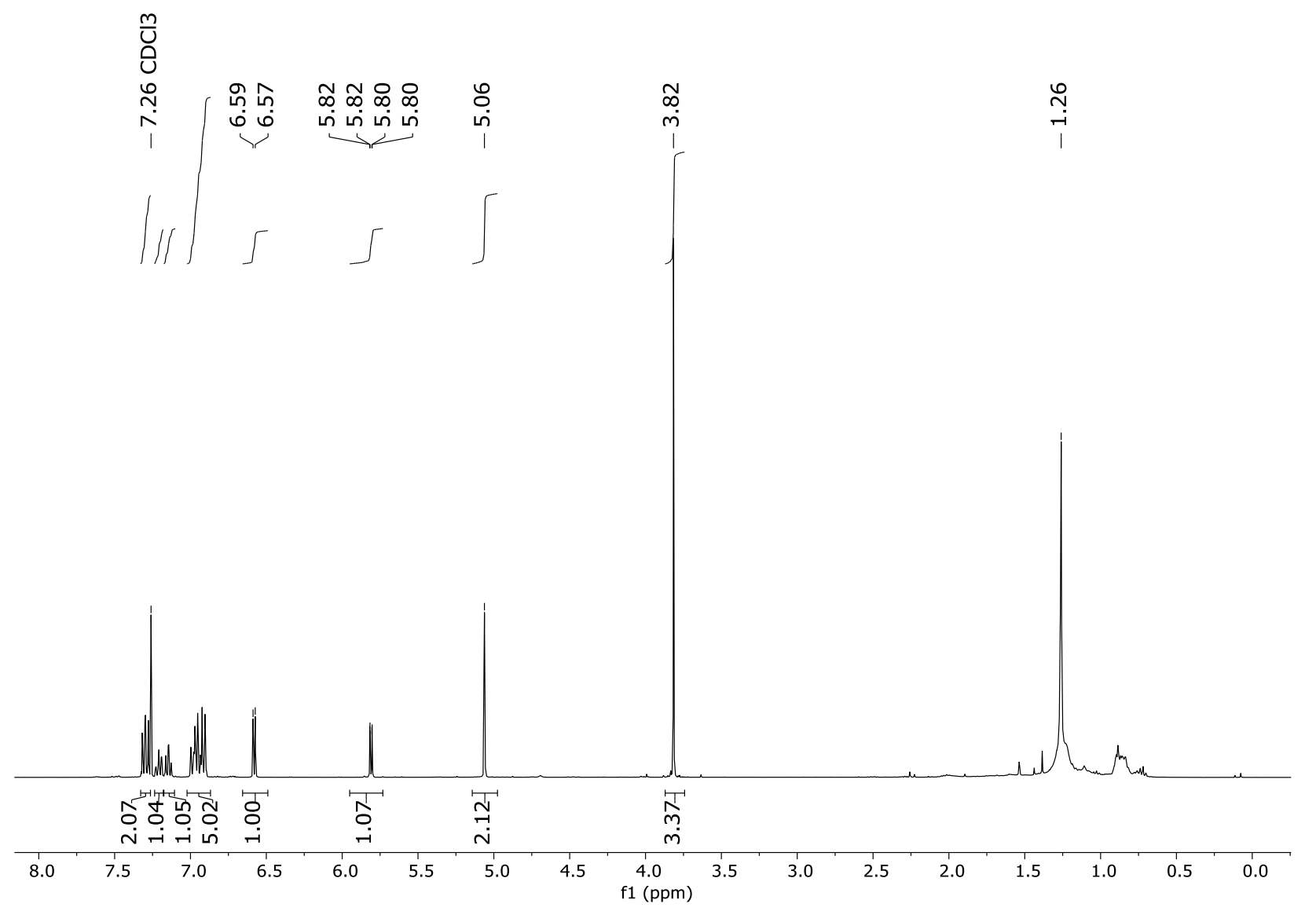

Figure S1. ${ }^{1} \mathrm{H}$ NMR spectrum of reaction mixture from $\mathbf{E B A}$ cyclization with complex $\mathbf{1 b}$ after silica plug and concentration under vacuum $\left(400 \mathrm{MHz}, \mathrm{CDCl}_{3}\right)$. 

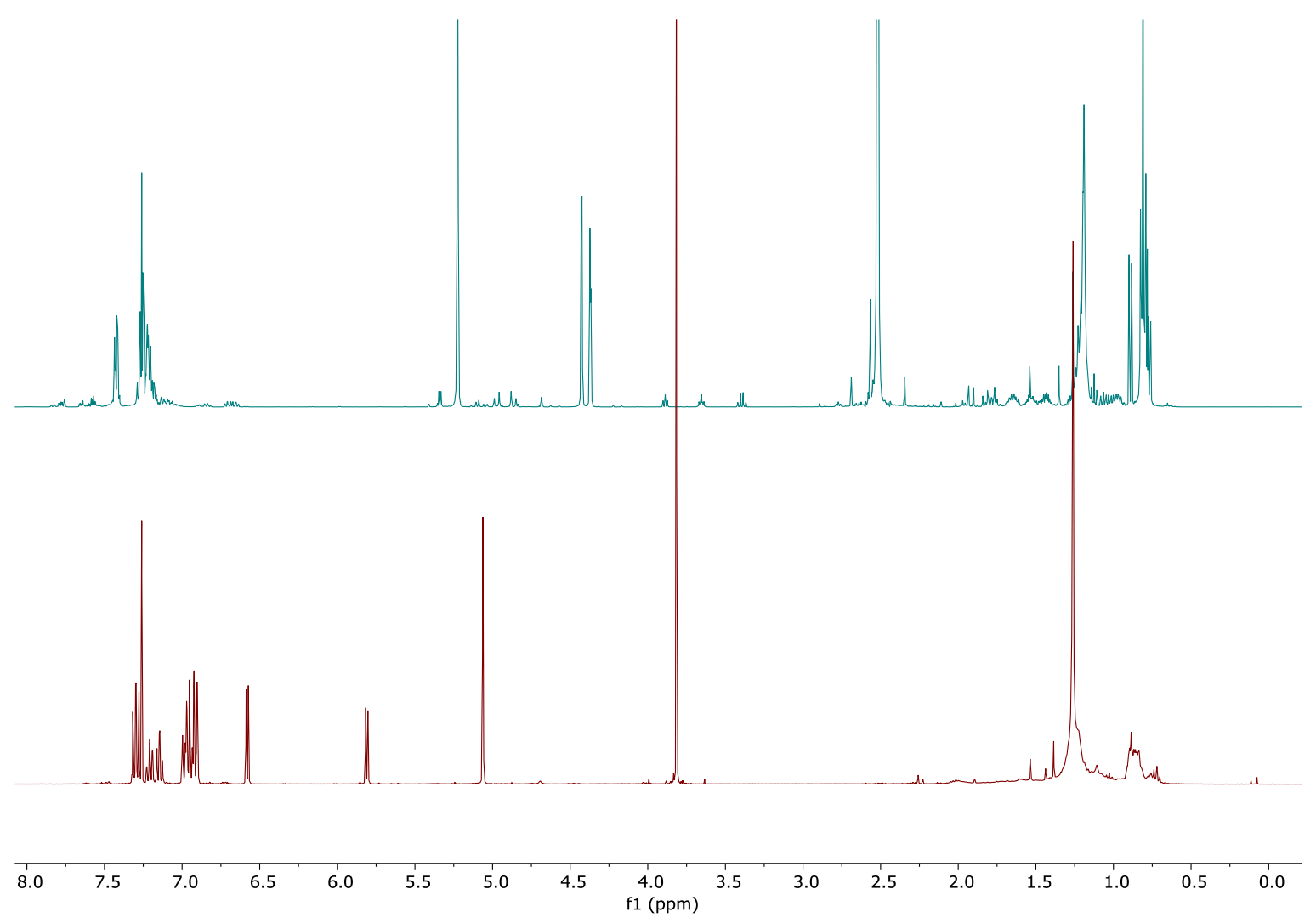

Figure S2. ${ }^{1} \mathrm{H}$ NMR spectra $\left(400 \mathrm{MHz}, \mathrm{CDCl}_{3}\right)$ of an authentic sample of 1-methylene-1,3dihydroisobenzofuran (top) and the isolated organics from the cycloisomerization of EBA cyclization with catalyst $\mathbf{1 b}$ (bottom). 


\section{II - NMR Spectra}

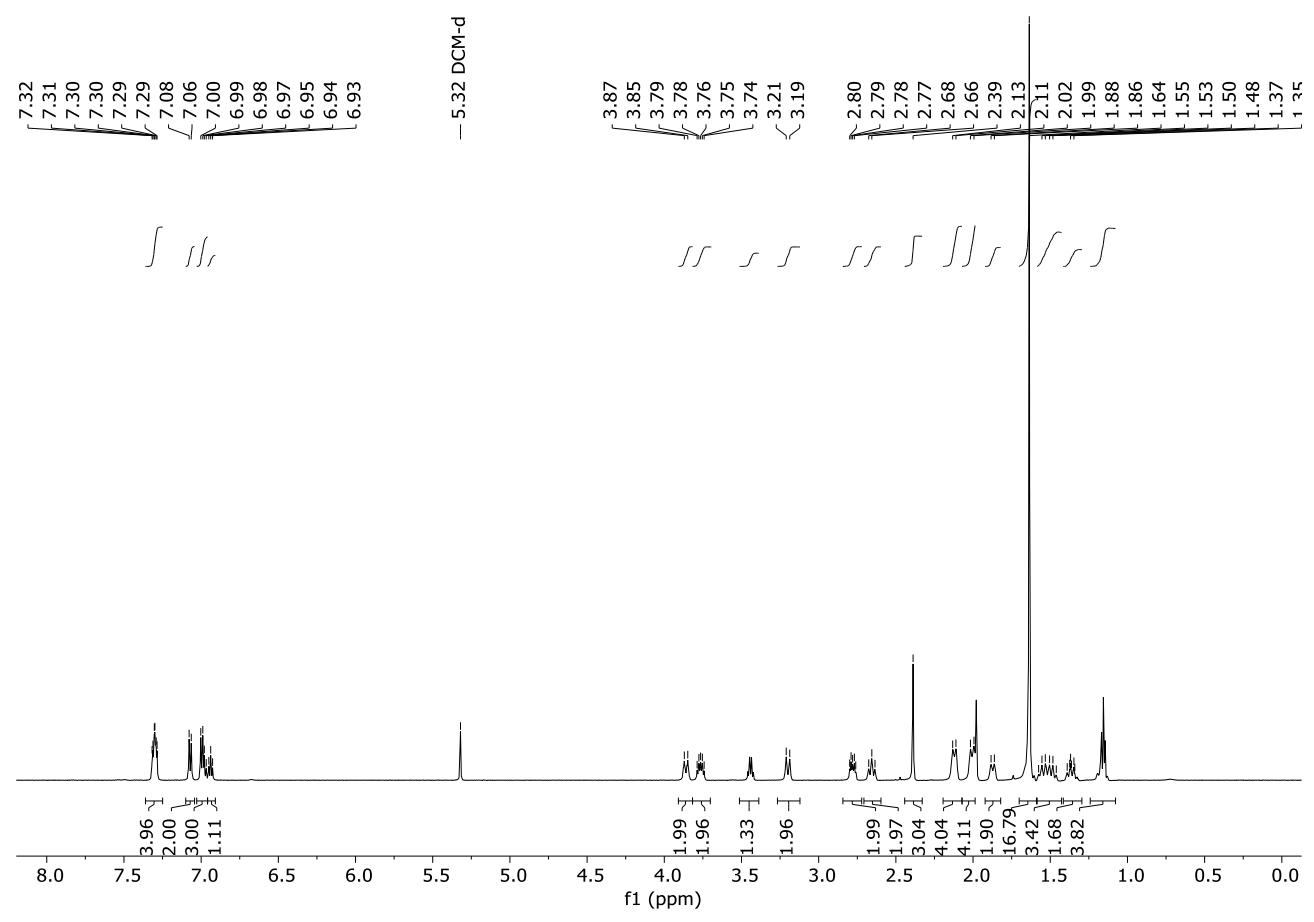

Figure S3. ${ }^{1} \mathrm{H}$ NMR spectrum of $1 \mathbf{a}\left(400 \mathrm{MHz}, \mathrm{CD}_{2} \mathrm{Cl}_{2}\right)$

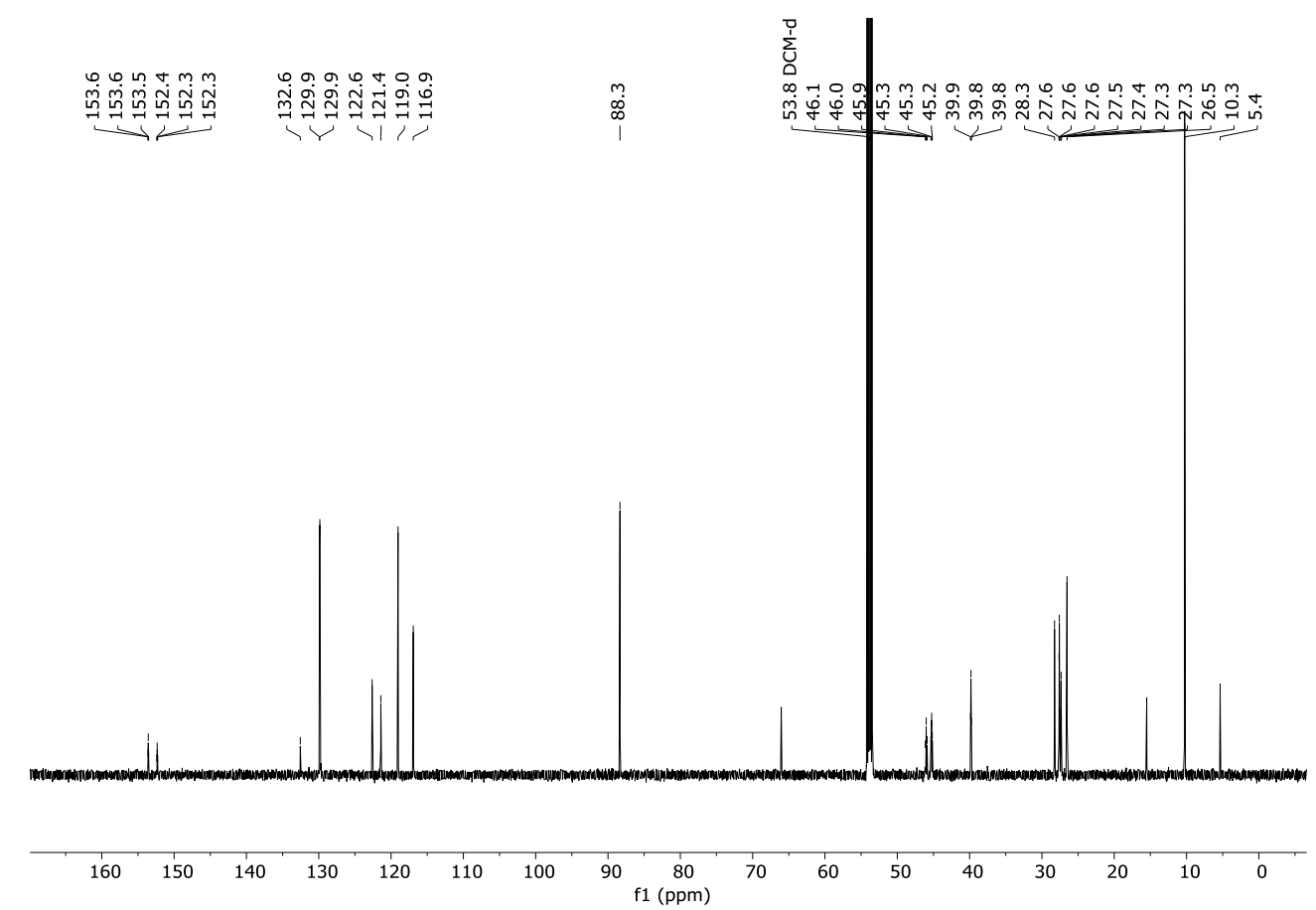

Figure S4. ${ }^{13} \mathrm{C}\left\{{ }^{1} \mathrm{H}\right\}$ NMR spectrum of $\mathbf{1 a}\left(101 \mathrm{MHz}, \mathrm{CD}_{2} \mathrm{Cl}_{2}\right)$ 


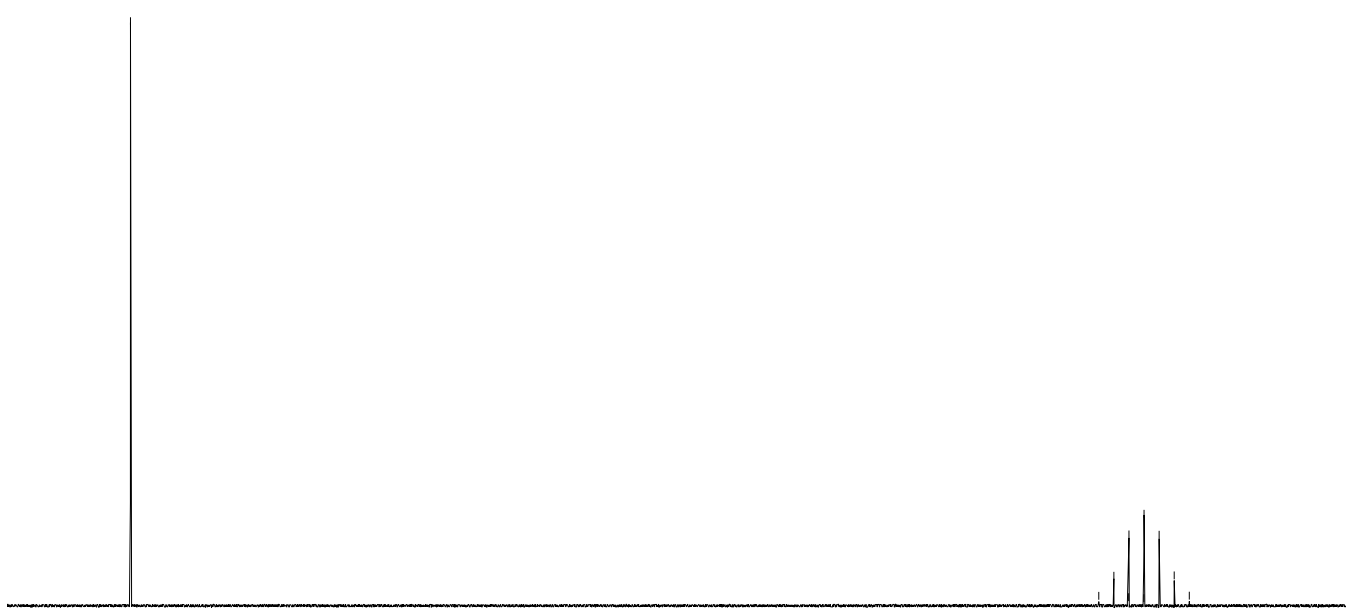

$\begin{array}{lllllllllllllllllllllllllllllll}70 & 60 & 50 & 40 & 30 & 20 & 10 & 0 & -10 & -20 & -30 & -40 & -50 & -60 & -70 & -80 & -90 & -100 & -110 & -120 & -130 & -140 & -150 & -160 & -170 & -18 c\end{array}$

Figure S5. ${ }^{31} \mathrm{P}\left\{{ }^{1} \mathrm{H}\right\}$ NMR spectrum of $\mathbf{1 a}\left(162 \mathrm{MHz}, \mathrm{CD}_{2} \mathrm{Cl}_{2}\right)$

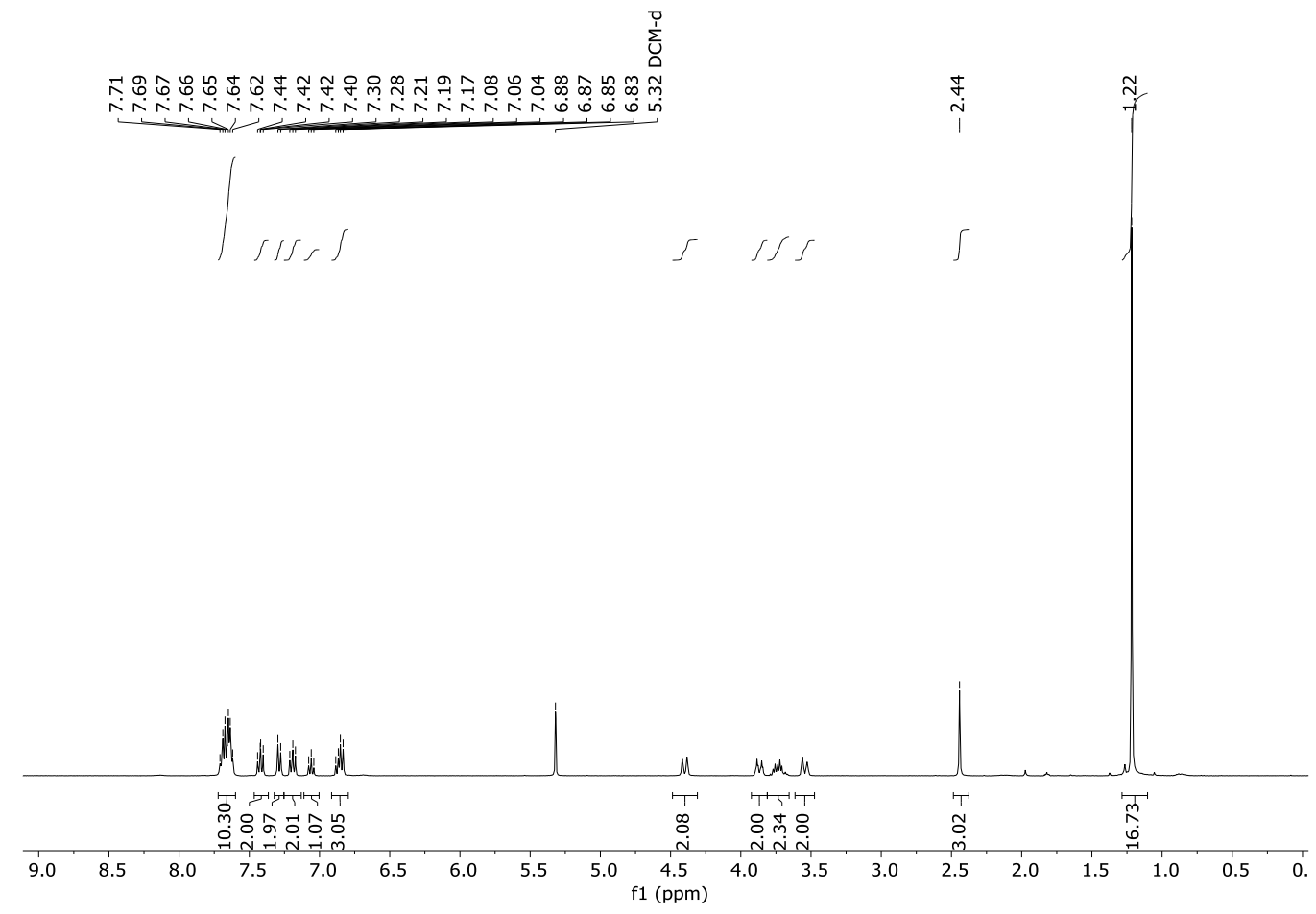

Figure S6. ${ }^{1} \mathrm{H}$ NMR Spectrum of $\mathbf{1 b}\left(400 \mathrm{MHz}, \mathrm{CD}_{2} \mathrm{Cl}_{2}\right)$ 


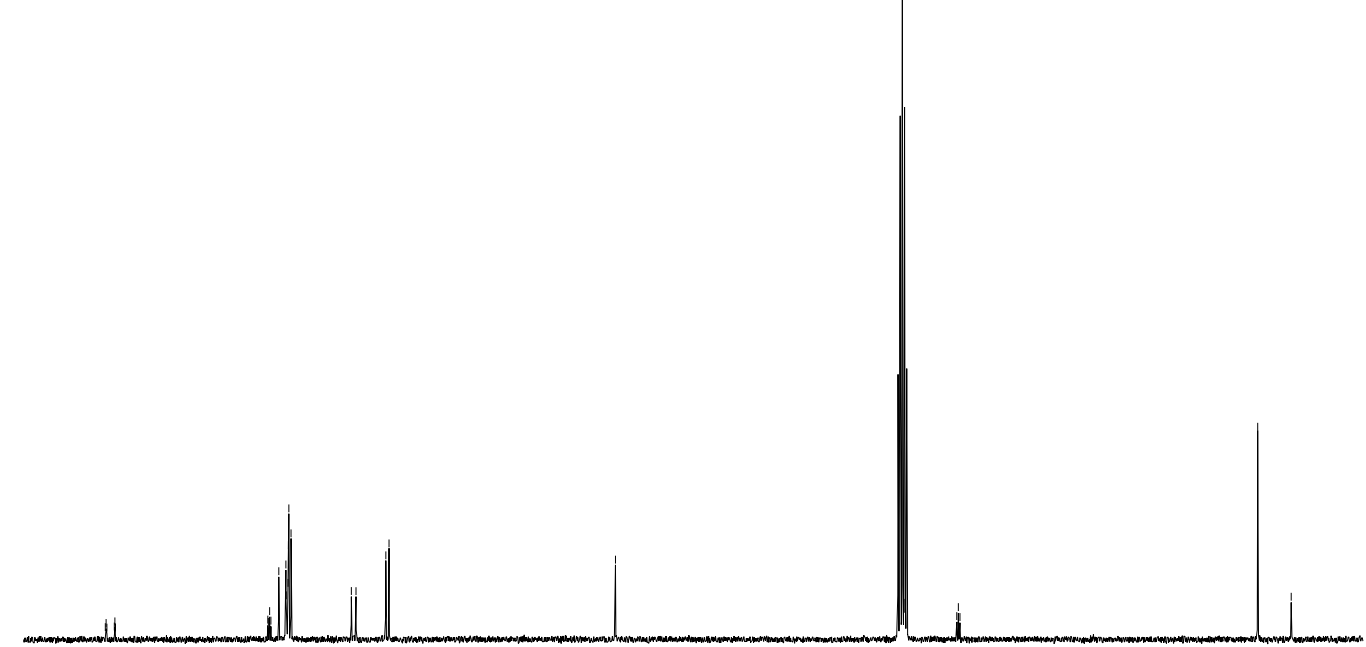

Figure S7. ${ }^{13} \mathrm{C}\left\{{ }^{1} \mathrm{H}\right\}$ NMR spectrum of $\mathbf{1 b}\left(101 \mathrm{MHz}, \mathrm{CD}_{2} \mathrm{Cl}_{2}\right)$

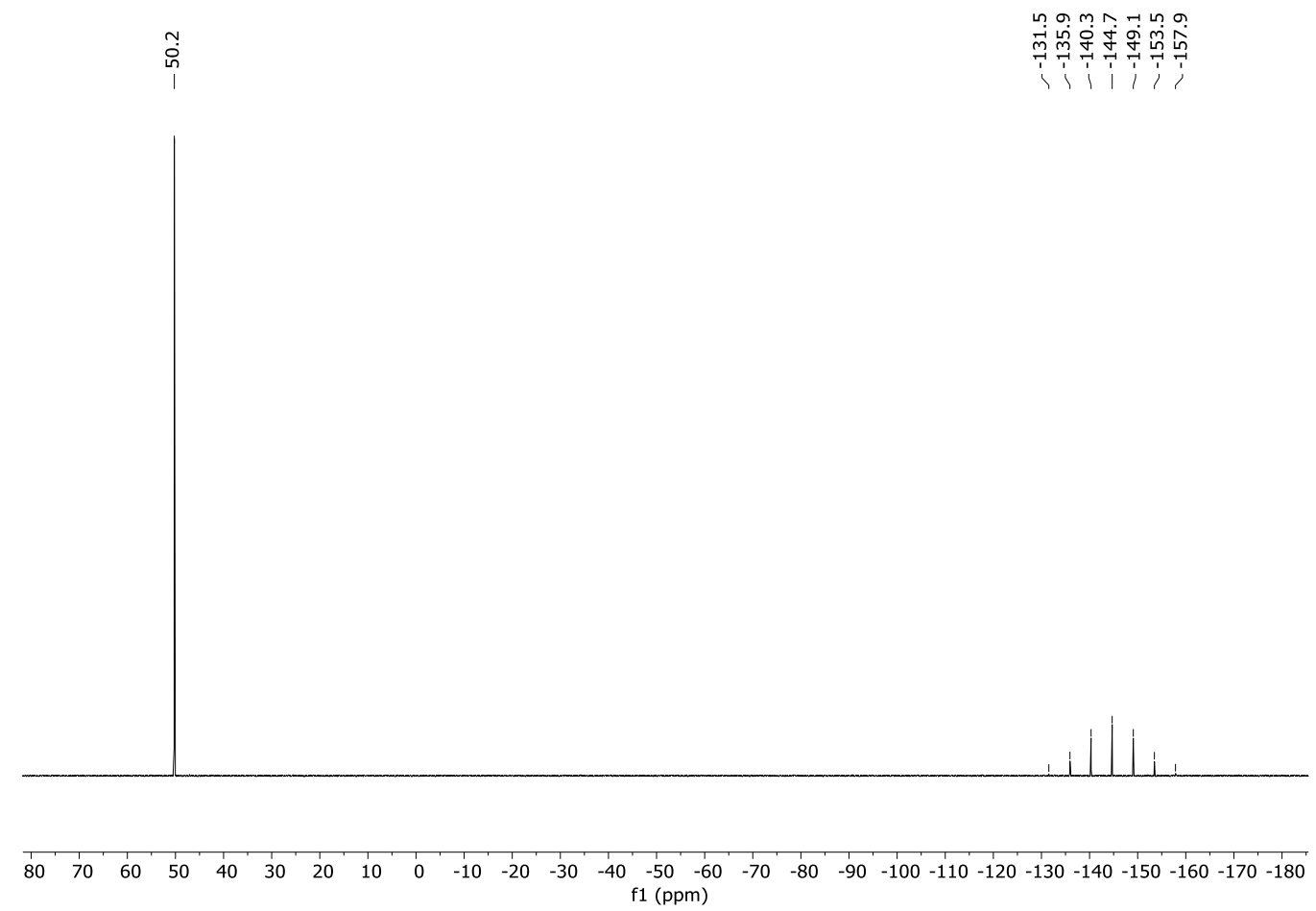

Figure S8. ${ }^{31} \mathrm{P}\left\{{ }^{1} \mathrm{H}\right\}$ NMR spectrum of $\mathbf{1 b}\left(162 \mathrm{MHz}, \mathrm{CD}_{2} \mathrm{Cl}_{2}\right)$ 


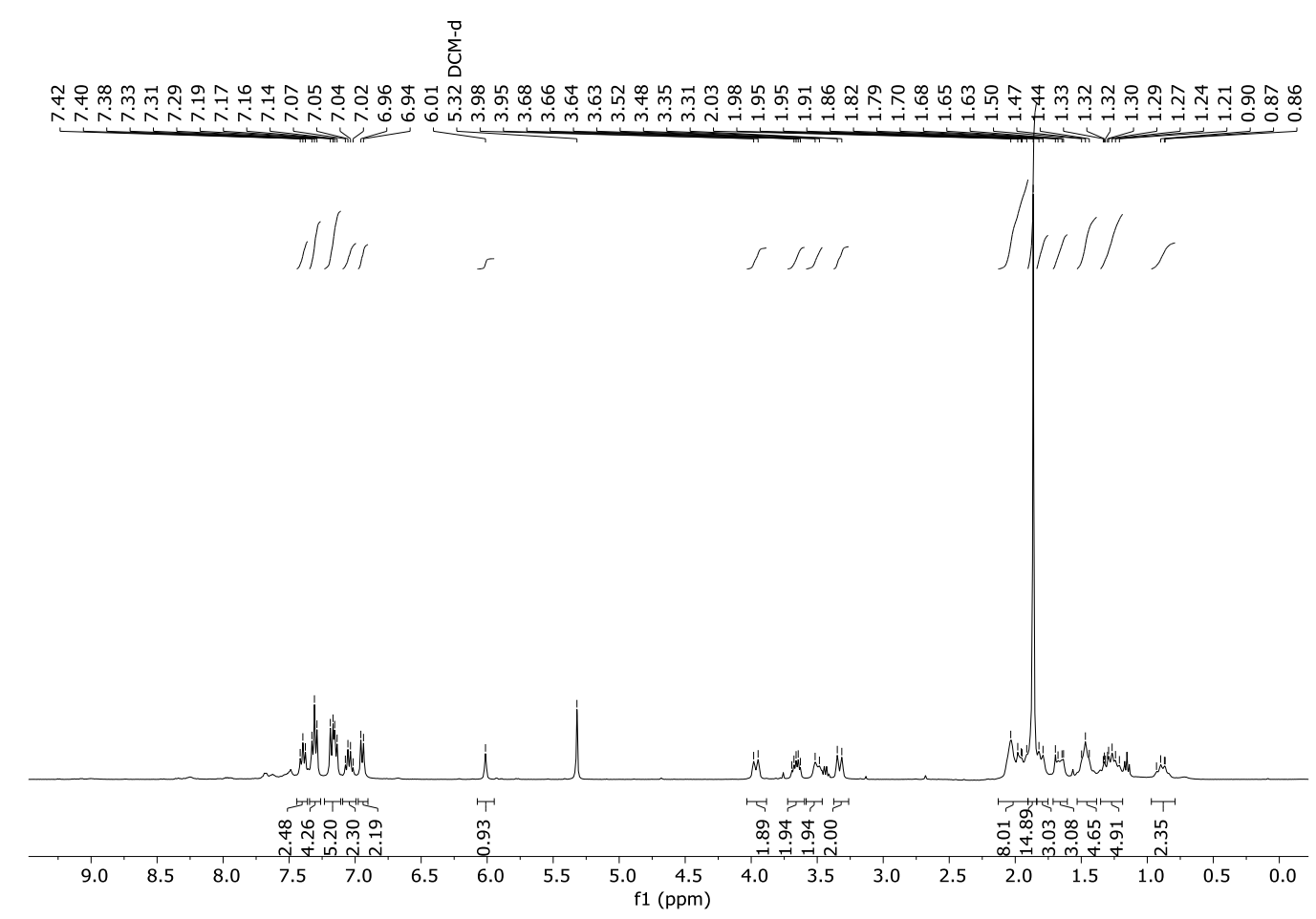

Figure S9. ${ }^{1} \mathrm{H} \mathrm{NMR}$ spectrum of $\mathbf{2 a}\left(400 \mathrm{MHz}, \mathrm{CD}_{2} \mathrm{Cl}_{2}\right)$

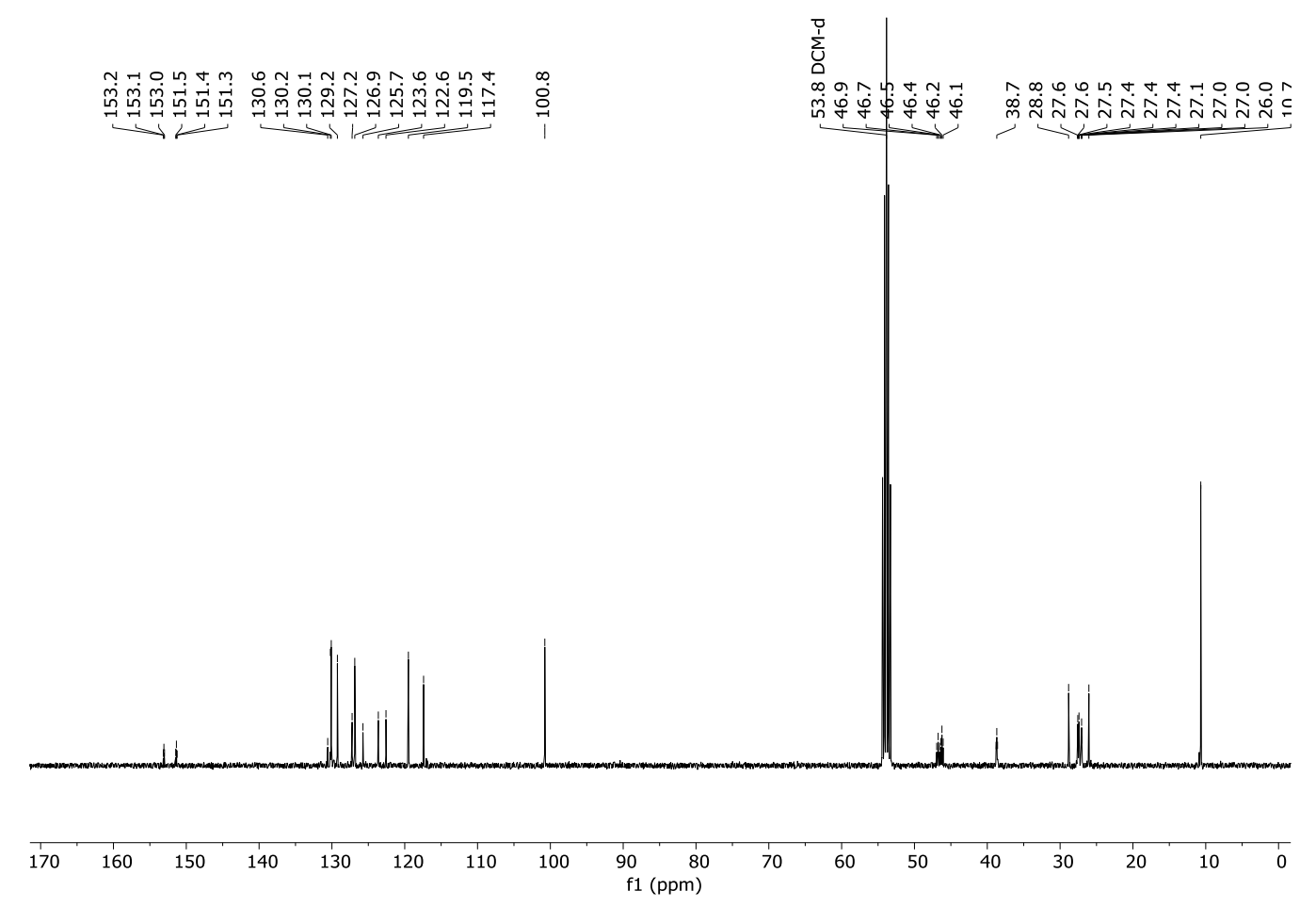

Figure S10. ${ }^{13} \mathrm{C}\left\{{ }^{1} \mathrm{H}\right\}$ NMR spectrum of 2a (101 MHz, $\left.\mathrm{CD}_{2} \mathrm{Cl}_{2}\right)$ 

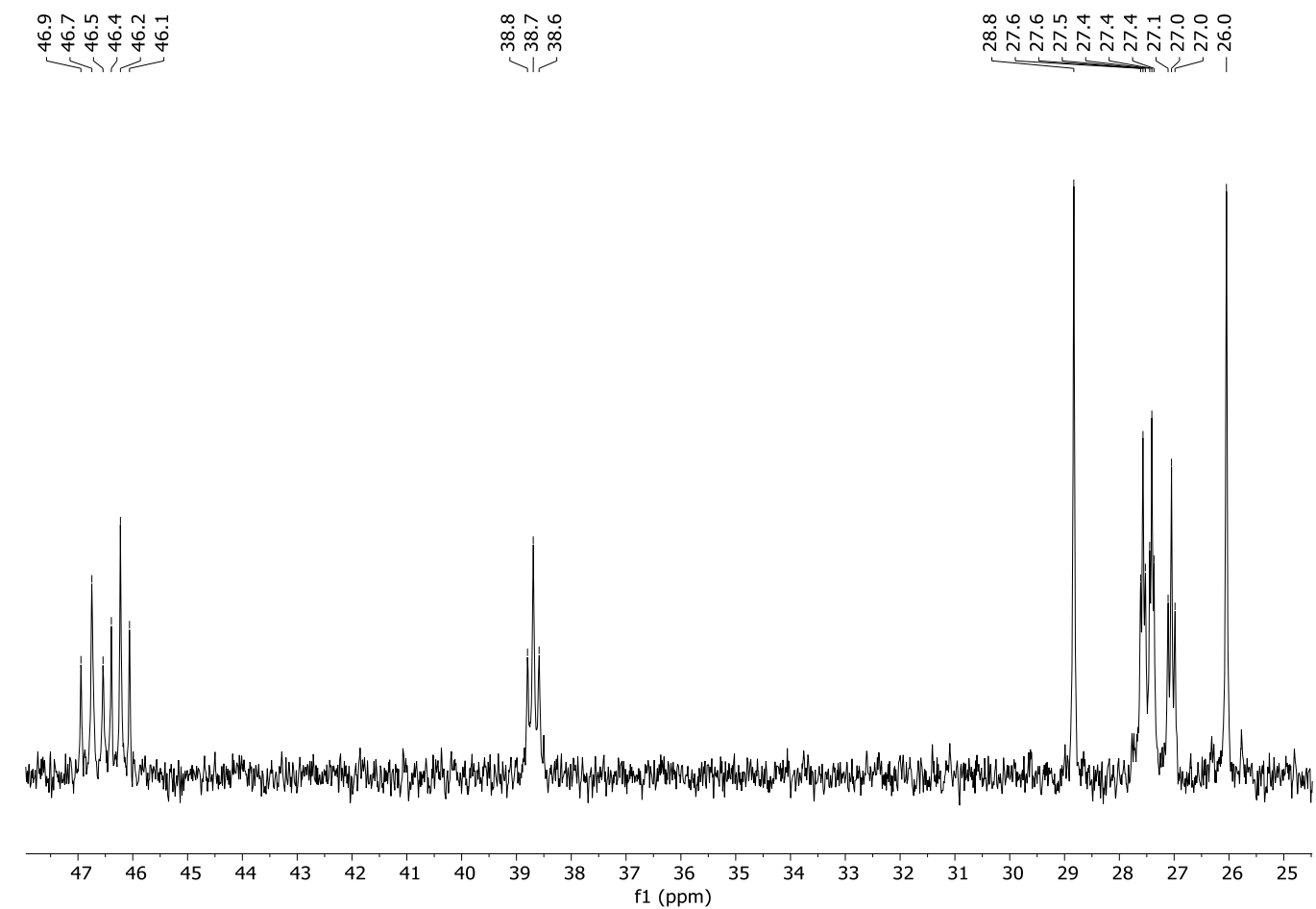

Figure S11. Expansion of the ${ }^{13} \mathrm{C}\left\{{ }^{1} \mathrm{H}\right\}$ NMR spectrum of $2 \mathbf{a}\left(162 \mathrm{MHz}, \mathrm{CD}_{2} \mathrm{Cl}_{2}\right)$ showing complex multiplets.

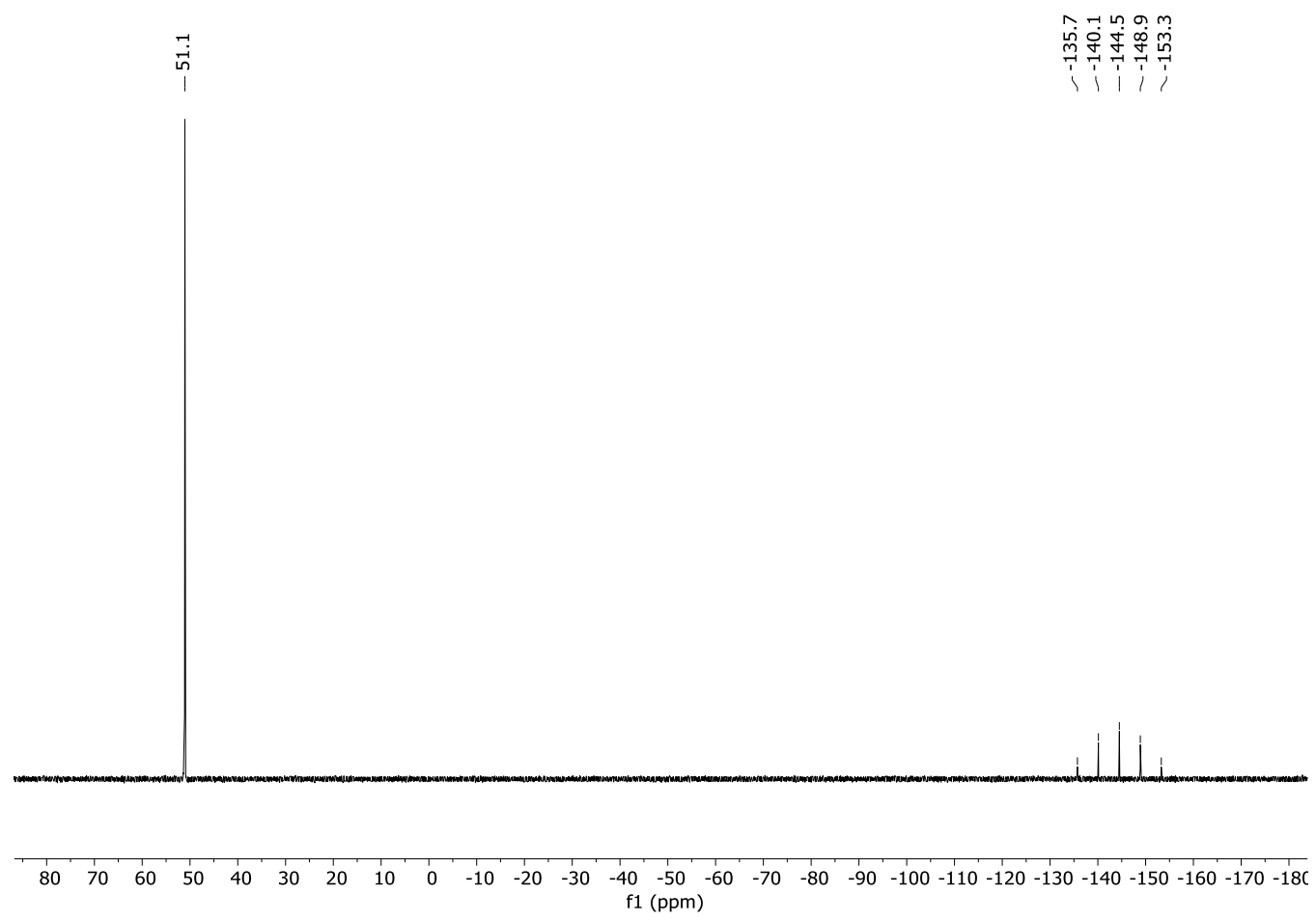

Figure S12. ${ }^{31} \mathrm{P}\left\{{ }^{1} \mathrm{H}\right\}$ NMR spectrum of $\mathbf{2 a}\left(162 \mathrm{MHz}, \mathrm{CD}_{2} \mathrm{Cl}_{2}\right)$ 


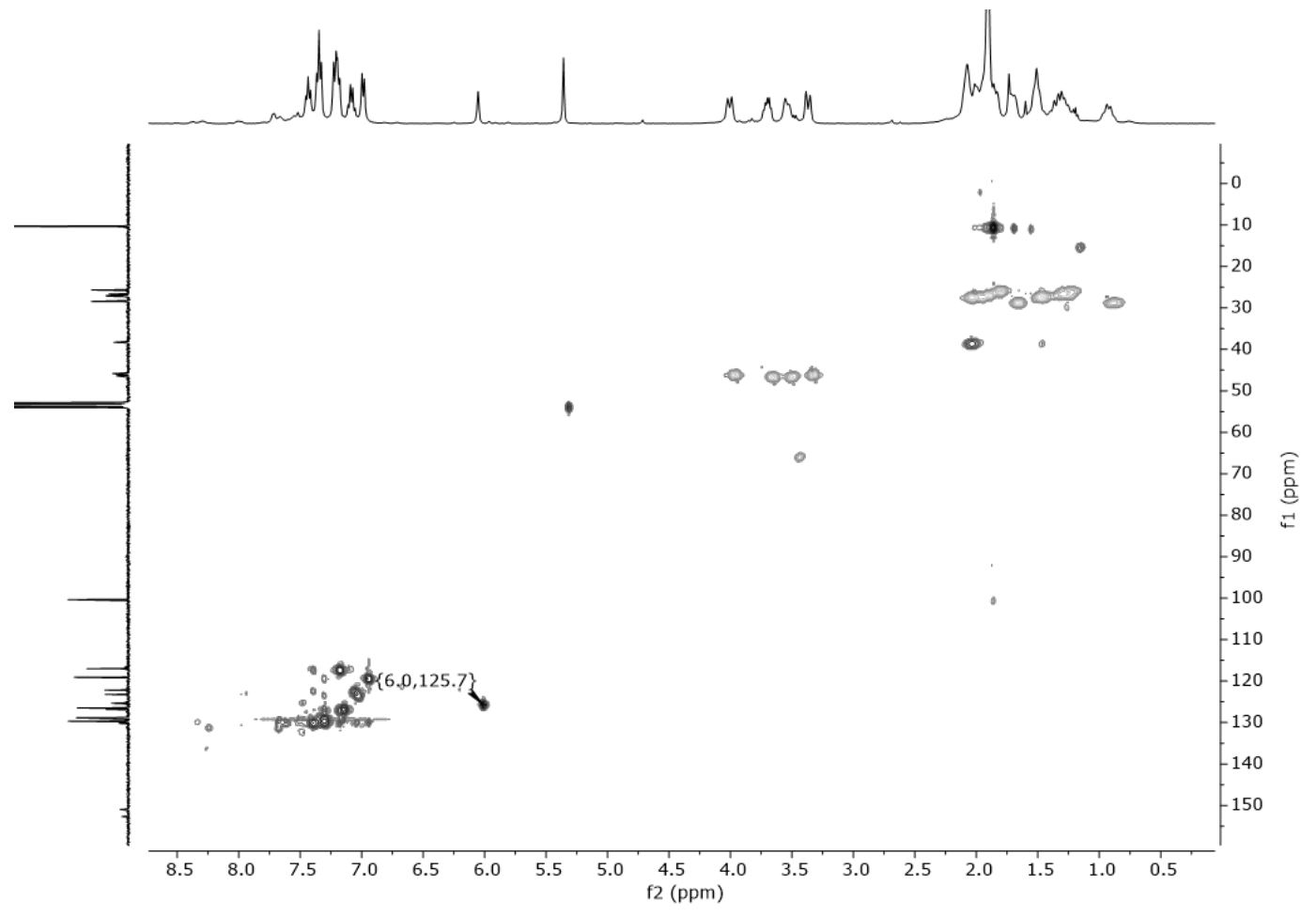

Figure S13. ${ }^{1} \mathrm{H}-{ }^{13} \mathrm{C} \mathrm{HSQC}$ spectrum of 2a (400 $\left.\mathrm{MHz}, \mathrm{CD}_{2} \mathrm{Cl}_{2}\right)$ showing $\mathrm{H}_{\beta}$ and $\mathrm{C}_{\beta}$ correlation

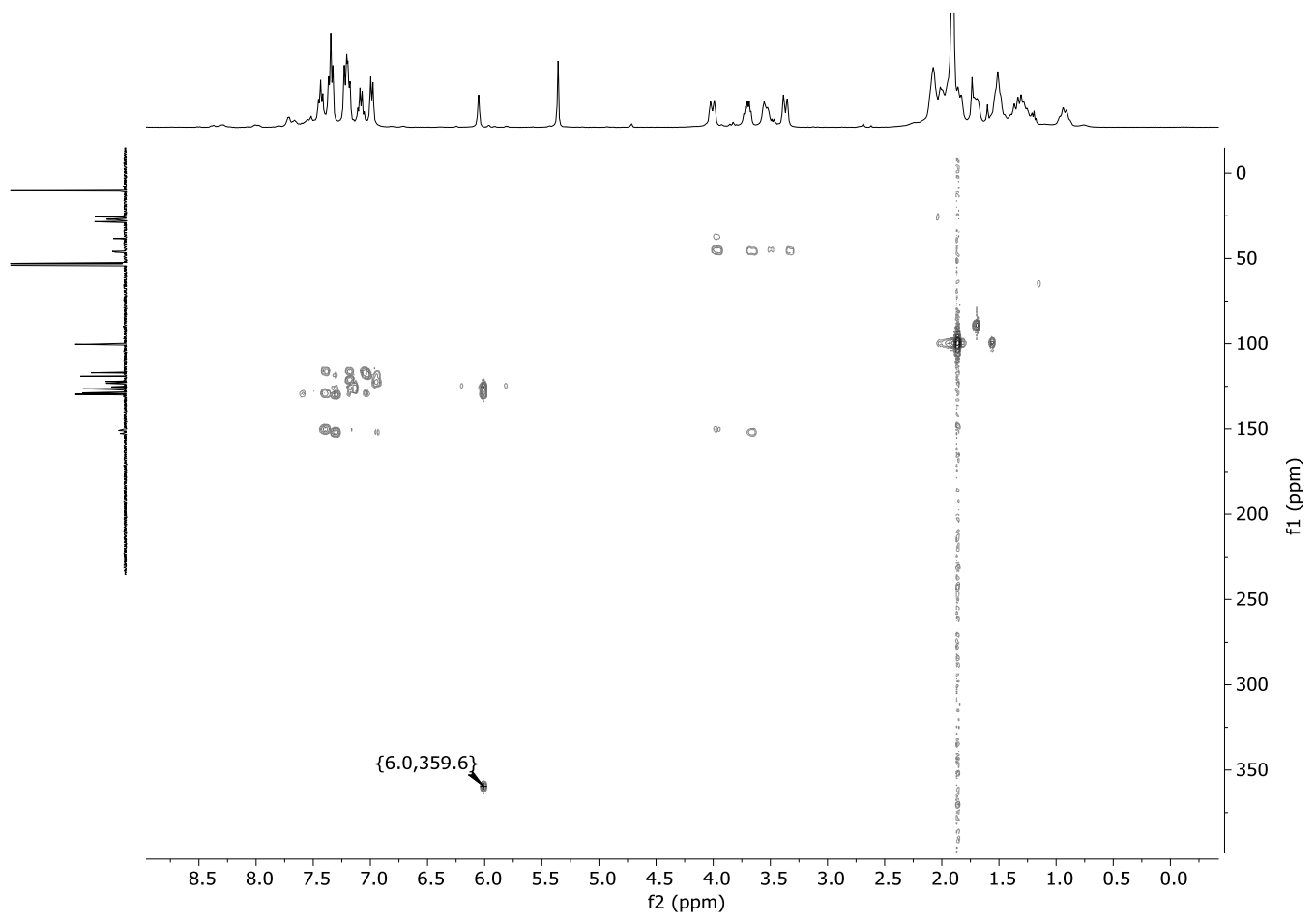

Figure S14. ${ }^{1} \mathrm{H}_{-}{ }^{13} \mathrm{C}$ HMBC spectrum of $\mathbf{2 a}\left(400 \mathrm{MHz}, \mathrm{CD}_{2} \mathrm{Cl}_{2}\right)$ showing $\mathrm{H}_{\beta}$ and $\mathrm{C}_{\alpha}$ correlation 
III - IR Spectra

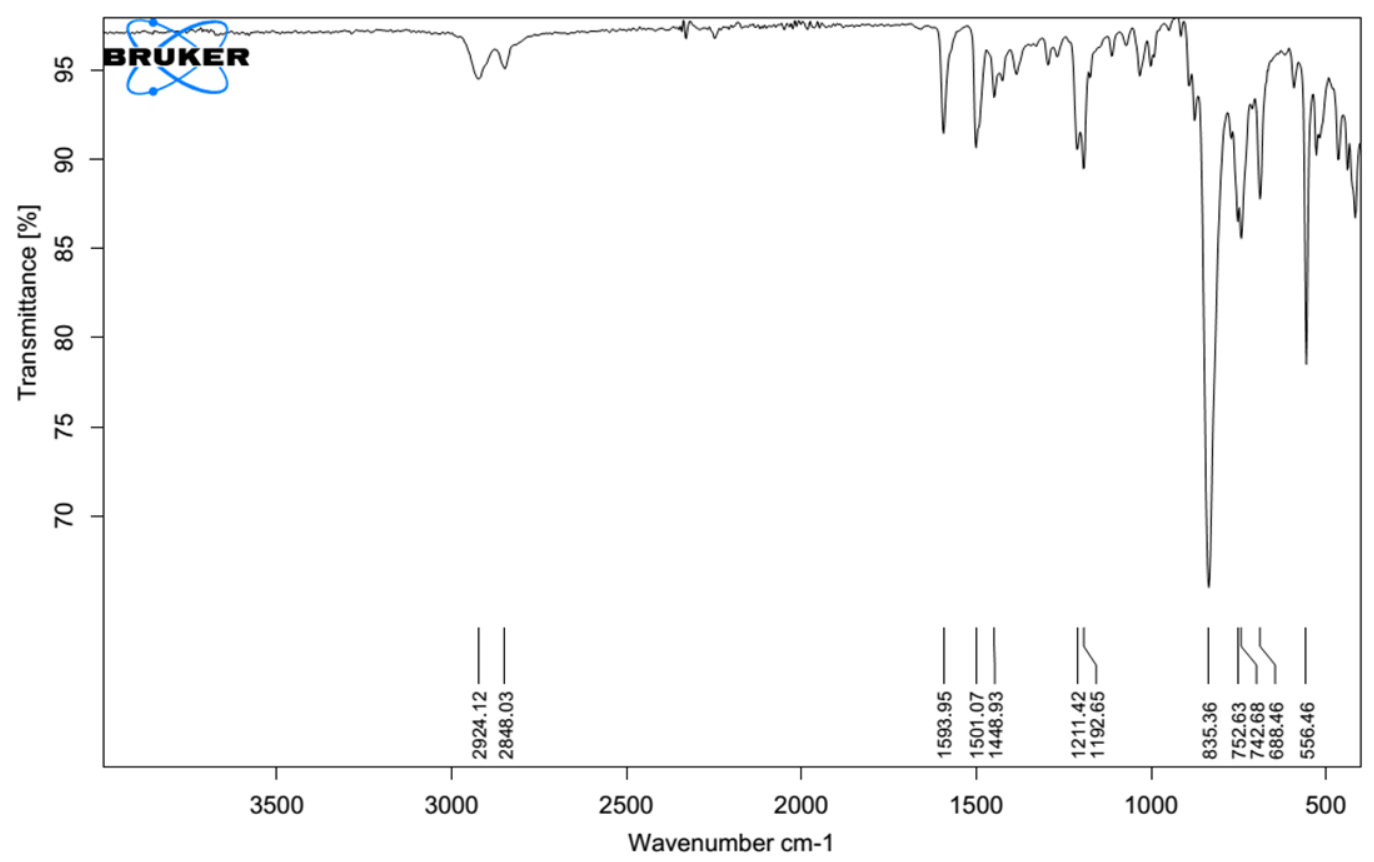

Figure S15. ATR-FTIR spectrum of solid 1a

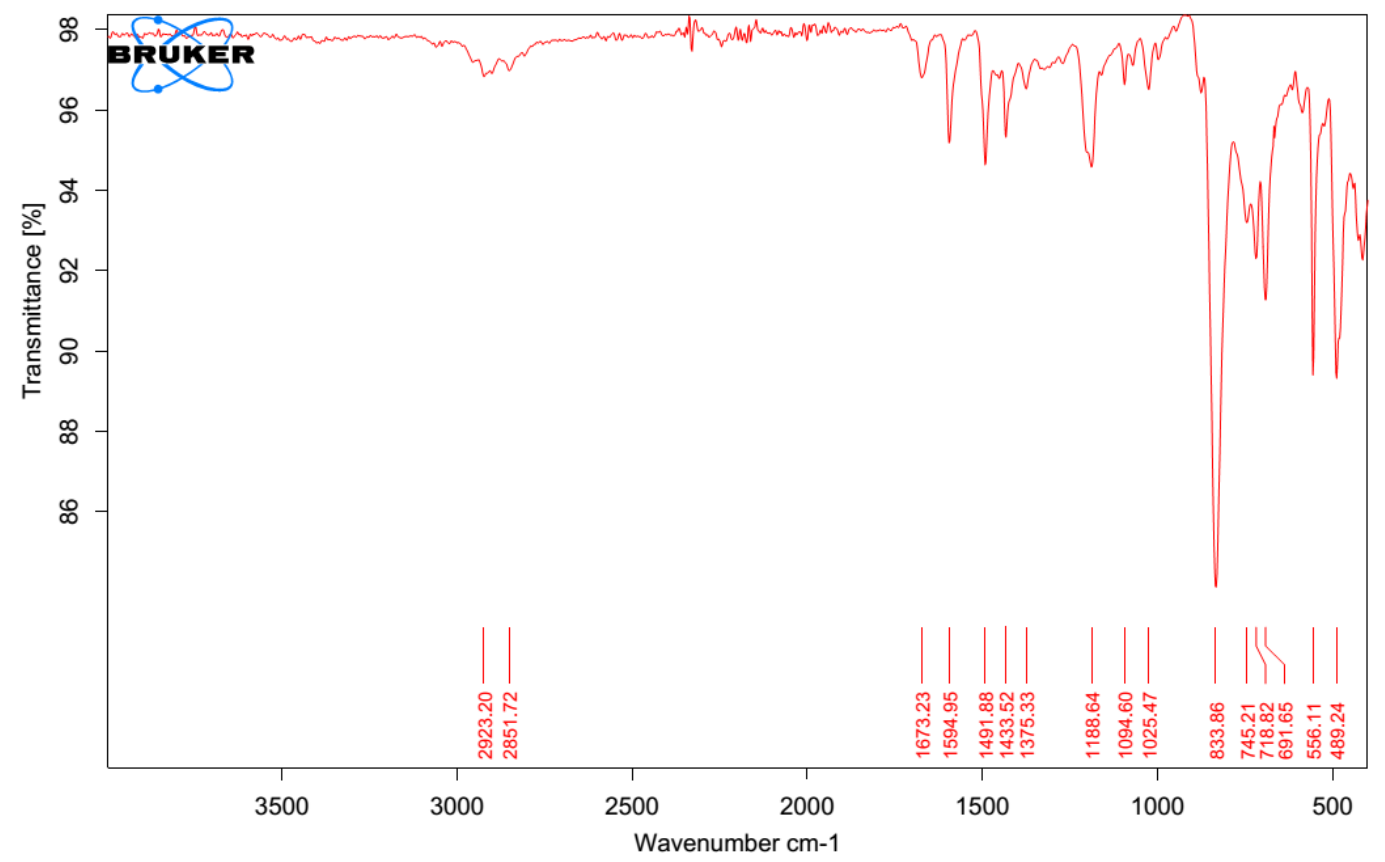

Figure S16. ATR-FTIR spectrum of solid $\mathbf{1 b}$ 


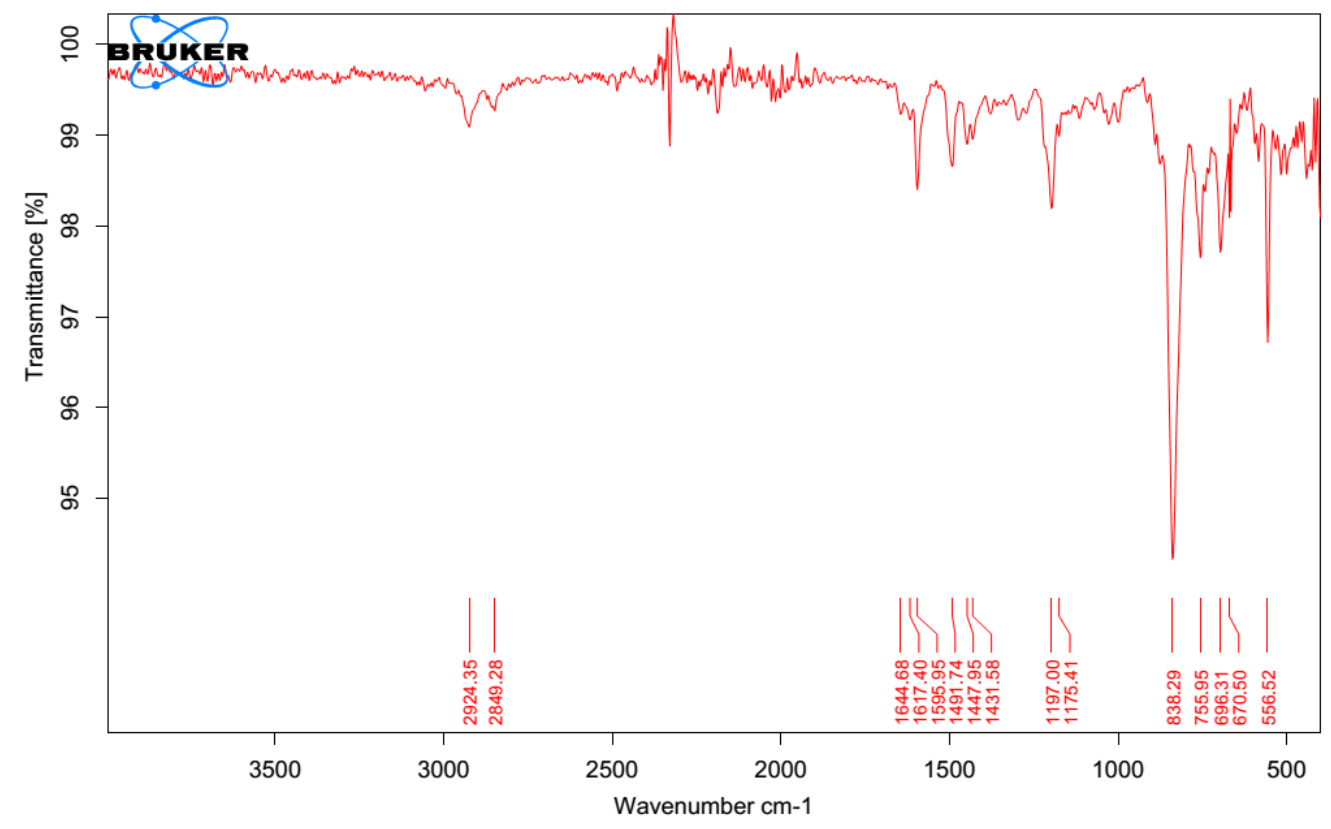

Figure S17. ATR-FTIR spectrum of solid 2a

\section{IV - MALDI Mass Spectra}

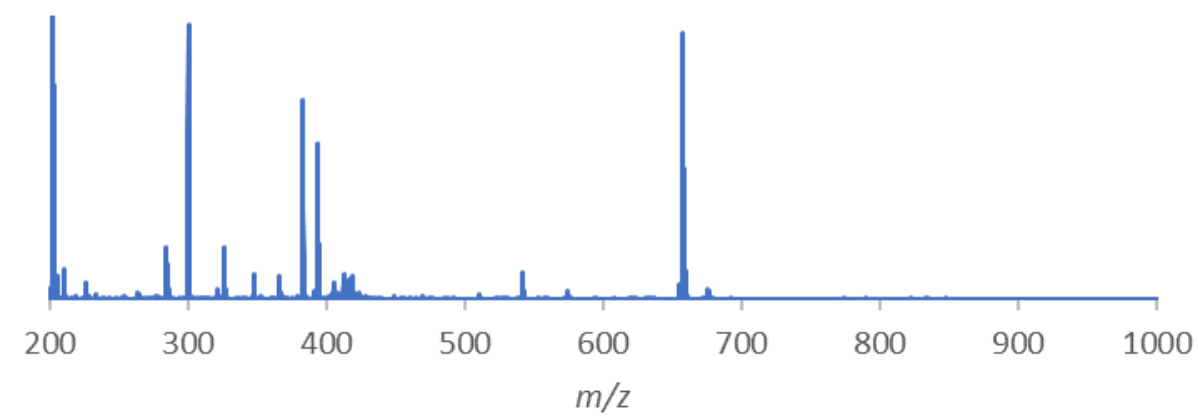

Figure S18. MALDI-TOF mass spectrum of $\left[\mathrm{Fe}\left(\mathrm{Cp}^{*}\right)\left(\mathrm{P}^{\mathrm{Cy}}{ }_{2} \mathrm{~N}^{\mathrm{Ph}}\right)(\mathrm{MeCN})\right] \mathrm{PF}_{6}(1 \mathrm{a})$ with pyrene as the matrix (1:20 molar ratio). Signal at $m / z=657.4$ represents $\left[\mathbf{1 a}-\mathrm{MeCN}_{-} \mathrm{PF}_{6}\right]^{+}$. 


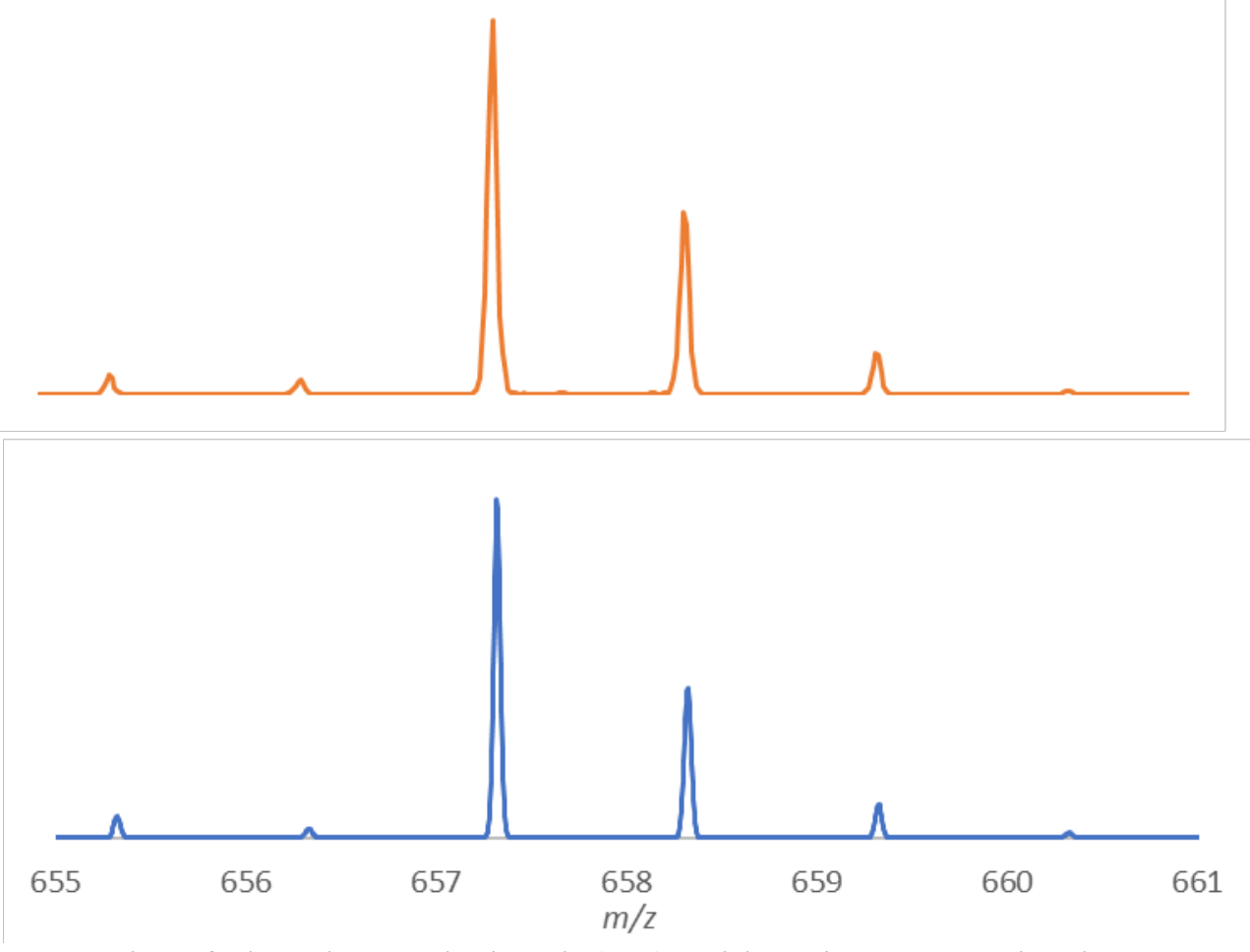

Figure S19. Zoom-in of the observed signal (top) with $m / z=657.4$ in the MALDI-TOF mass spectrum of $\left[\mathrm{Fe}\left(\mathrm{Cp}^{*}\right)\left(\mathrm{P}^{\mathrm{Cy}}{ }_{2} \mathrm{~N}^{\mathrm{Ph}}\right)(\mathrm{MeCN})\right] \mathrm{PF}_{6}(\mathbf{1 a})$; and simulation ${ }^{8}$ (bottom) of the isotope pattern for the fragment cation $\left[\mathrm{Fe}\left(\mathrm{Cp}^{*}\right)\left(\mathrm{P}^{\mathrm{Cy}}{ }_{2} \mathrm{~N}_{2}^{\mathrm{Ph}}\right)\right]^{+}$with $m / z=657.3$.

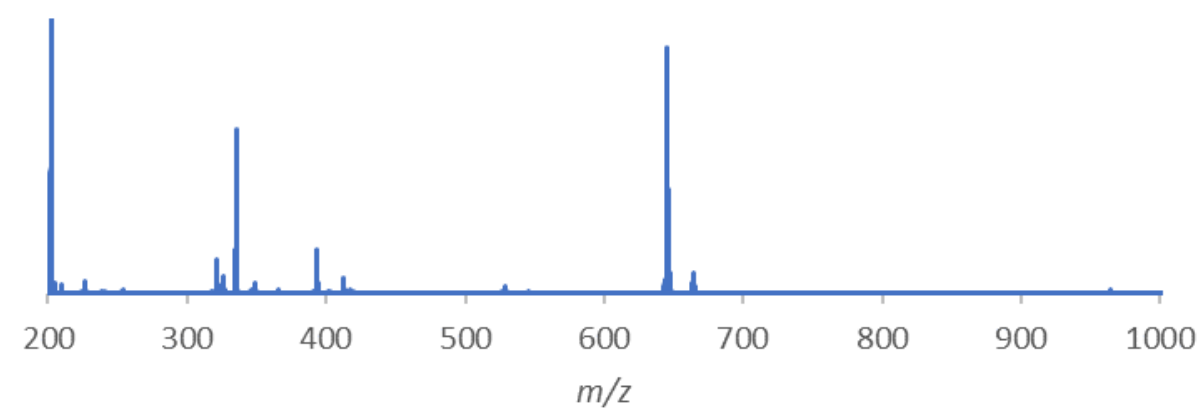

Figure S20. MALDI-TOF mass spectrum of $\left[\mathrm{Fe}\left(\mathrm{Cp}^{*}\right)\left(\mathrm{P}_{2}^{\mathrm{Ph}} \mathrm{N}^{\mathrm{Ph}}\right)(\mathrm{MeCN})\right] \mathrm{PF}_{6}(\mathbf{1 b})$ with pyrene as the matrix (1:20 molar ratio). Signal at $m / z=645.2$ represents $\left[\mathbf{1 b}-\mathrm{MeCN}_{-} \mathrm{PF}_{6}\right]^{+}$. 


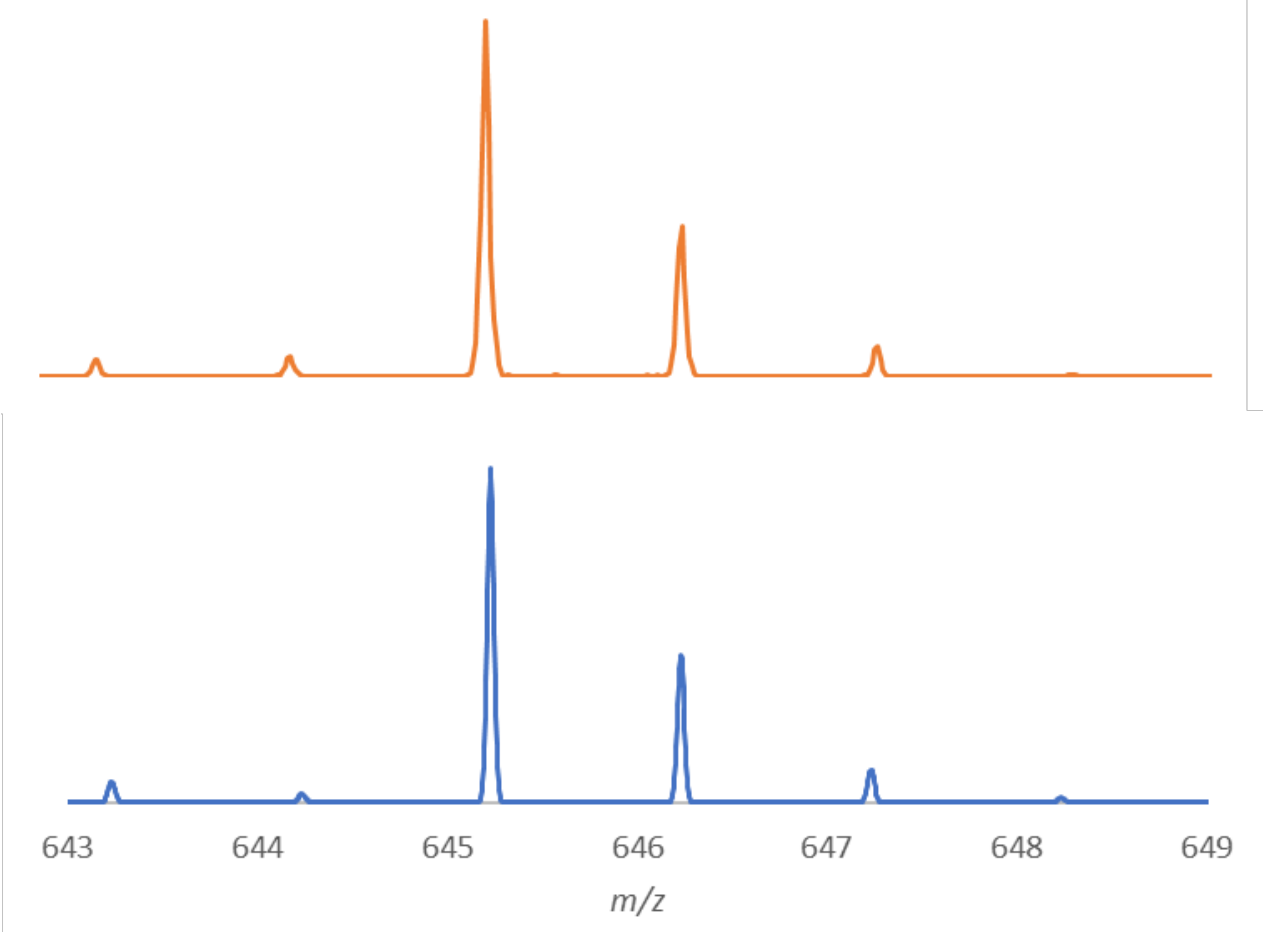

Figure S21. Zoom-in of the observed signal (top) with $m / z=645.2$ in the MALDI-TOF mass spectrum of $\left[\mathrm{Fe}\left(\mathrm{Cp}^{*}\right)\left(\mathrm{P}^{\mathrm{Ph}}{ }_{2} \mathrm{~N}^{\mathrm{Ph}}\right)(\mathrm{MeCN})\right] \mathrm{PF}_{6}(\mathbf{1 b})$; and simulation ${ }^{8}$ (bottom) of the isotope pattern for the fragment cation $\left[\mathrm{Fe}\left(\mathrm{Cp}^{*}\right)\left(\mathrm{P}^{\mathrm{Ph}}{ }_{2} \mathrm{~N}^{\mathrm{Ph}}{ }_{2}\right)\right]^{+}$with $m / z=645.2$.

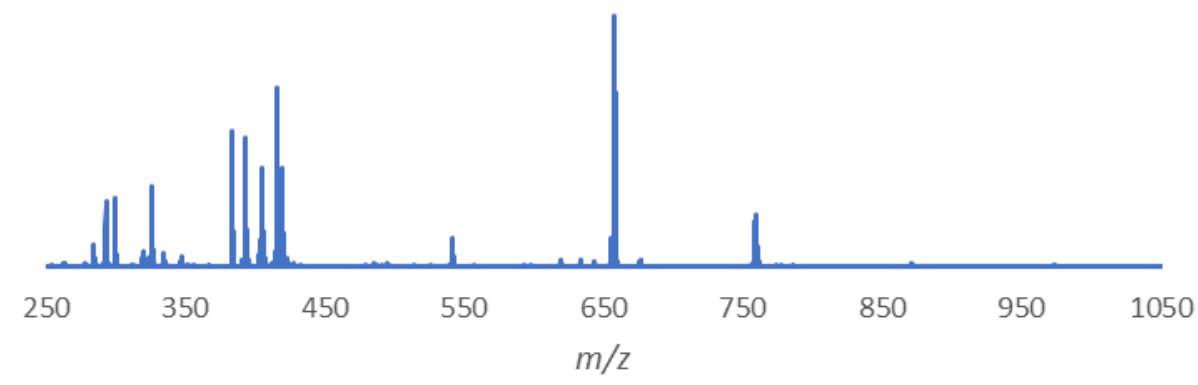

Figure S22. MALDI-TOF mass spectrum of $\left[\mathrm{Fe}\left(\mathrm{Cp}^{*}\right)\left(\mathrm{P}^{\mathrm{Cy}}{ }_{2} \mathrm{~N}_{2}{ }_{2}\right)(\mathrm{C}=\mathrm{CHPh})\right] \mathrm{PF}_{6}$ (2a) with pyrene as the matrix $\left(1: 20\right.$ molar ratio). Signal at $\mathrm{m} / z=759.4$ represents $\left[2 \mathbf{a}-\mathrm{PF}_{6}\right]^{+}$; signal at $\mathrm{m} / z=657.4$ represents $\left[\mathbf{2 a}-(\mathrm{C}=\mathrm{CHPh})-\mathrm{PF}_{6}\right]^{+}$. 

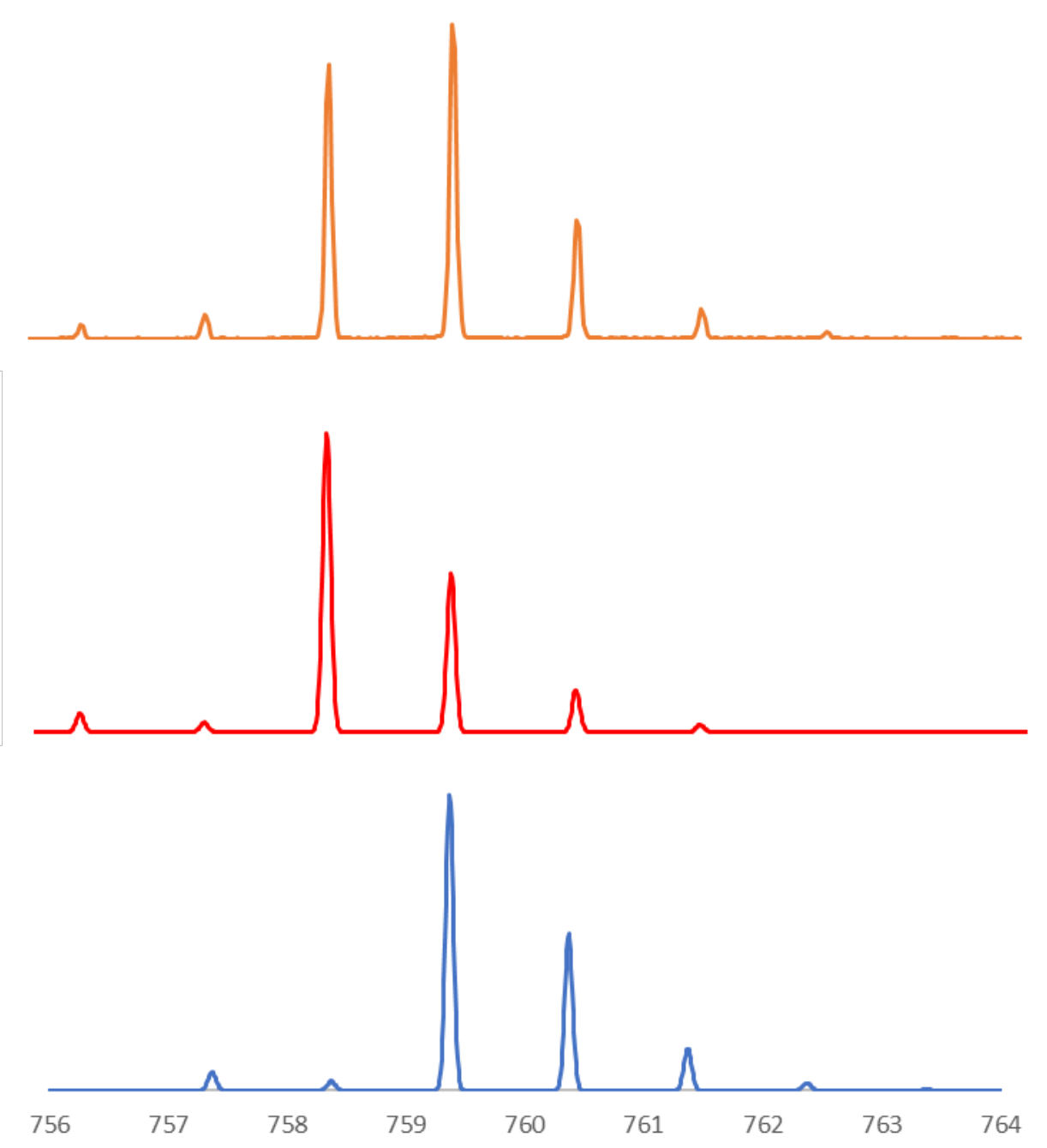

Figure S23. Zoom-in of the observed signal (top) with $m / z=759.4$ in the MALDI-TOF mass spectrum of $\left[\mathrm{Fe}\left(\mathrm{Cp}^{*}\right)\left(\mathrm{P}^{\mathrm{Cy}}{ }_{2} \mathrm{~N}^{\mathrm{Ph}}{ }_{2}\right)(\mathrm{C}=\mathrm{CHPh})\right] \mathrm{PF}_{6}$ (2a); simulations ${ }^{8}$ of the isotope pattern for the fragment cation $\left[\mathrm{Fe}\left(\mathrm{Cp}^{*}\right)\left(\mathrm{P}^{\mathrm{Cy}}{ }_{2} \mathrm{~N}^{\mathrm{Ph}}\right)(\mathrm{C}=\mathrm{CHPh})-\mathrm{H}\right]^{+}$with $m / z=758.4$ (middle) and of the isotope pattern for the fragment cation $\left[\mathrm{Fe}\left(\mathrm{Cp}^{*}\right)\left(\mathrm{P}^{\mathrm{Cy}}{ }_{2} \mathrm{~N}^{\mathrm{Ph}}{ }_{2}\right)(\mathrm{C}=\mathrm{CHPh})\right]^{+}$with $m / z=759.4$ (bottom). 


\section{V - Crystallographic Details}

Data Collection and Processing. The sample was mounted on a Mitegen polyimide micromount with a small amount of Paratone $\mathrm{N}$ oil. All X-ray measurements were made on a Bruker Kappa Axis Apex2 diffractometer at a temperature of $110 \mathrm{~K}$. The unit cell dimensions were determined from a symmetry constrained fit of 9104 reflections with $5.76^{\circ}<2 \theta<67.32^{\circ}$. The data collection strategy was a number of $\omega$ and $\varphi$ scans which collected data up to $72.784^{\circ}(2 \theta)$. The frame integration was performed using SAINT. ${ }^{9}$ The resulting raw data was scaled and absorption corrected using a multiscan averaging of symmetry equivalent data using SADABS. ${ }^{10}$

Structure Solution and Refinement. The structure was solved by using a dual space methodology using the SHELXT program. ${ }^{11}$ All non-hydrogen atoms were obtained from the initial solution. The hydrogen atoms were introduced at idealized positions and were allowed to ride on the parent atom. The structural model was fit to the data using full matrix least-squares based on $F^{2}$. The calculated structure factors included corrections for anomalous dispersion from the usual tabulation. The structure was refined using the SHELXL program from the SHELXTL suite of crystallographic software. ${ }^{12}$ Graphic plots were produced using the Mercury program suite. ${ }^{13}$

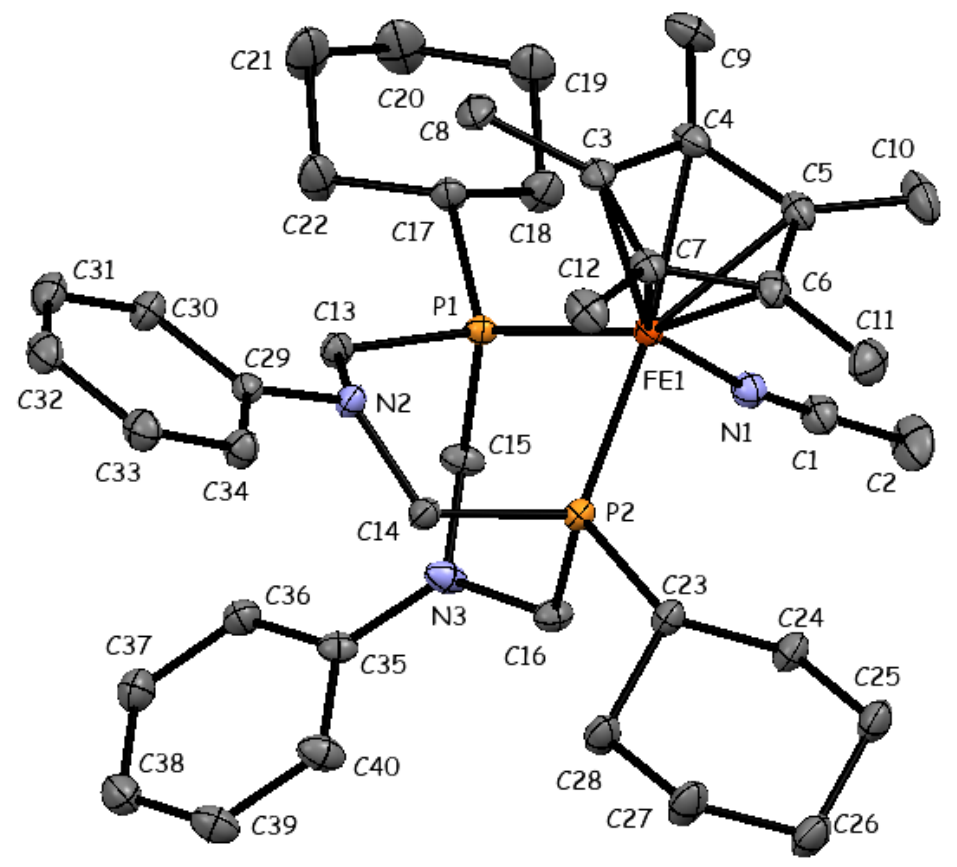

Figure S24. ORTEP drawing of $1 \boldsymbol{a}$ showing naming and numbering scheme. Ellipsoids are at the $50 \%$ probability level. Hydrogen atoms, the $\mathrm{PF}_{6}{ }^{-}$anion and an $\mathrm{MeCN}$ molecule of solvation were omitted for clarity. 


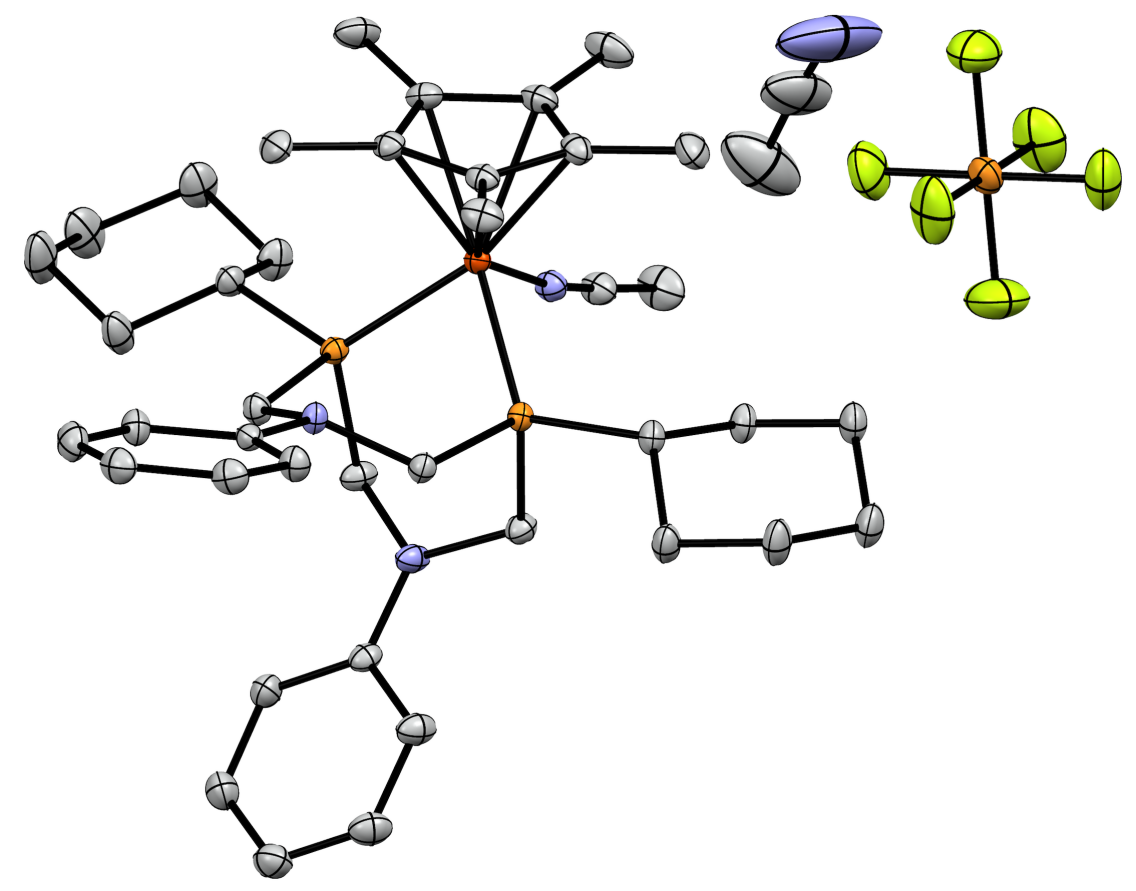

Figure S25. ORTEP drawing of $1 \boldsymbol{a}$. Ellipsoids are at the 50\% probability level and hydrogen atoms were omitted for clarity. 
Table S2. Summary of Crystal Data for 1a

Formula

CCDC

Formula Weight $(\mathrm{g} / \mathrm{mol})$

Crystal Dimensions ( $\mathrm{mm}$ )

Crystal Color and Habit

Crystal System

Space Group

Temperature, $\mathrm{K}$

$a, \AA$

$b, \AA$

$c, \AA$

$\alpha,{ }^{\circ}$

$\beta,{ }^{\circ}$

$\gamma,{ }^{\circ}$

$\mathrm{V}, \AA^{3}$

Number of reflections to determine final unit cell

Min and Max $2 \theta$ for cell determination, ${ }^{\circ}$

Z

$\mathrm{F}(000)$

$\rho(\mathrm{g} / \mathrm{cm})$

$\lambda, \AA,(\mathrm{MoK} \alpha)$

$\mu,\left(\mathrm{cm}^{-1}\right)$

Diffractometer Type

Scan Type(s)

Max $2 \theta$ for data collection, ${ }^{\circ}$

Measured fraction of data

Number of reflections measured

Unique reflections measured

$\mathrm{R}_{\text {merge }}$

Number of reflections included in refinement
$\mathrm{C}_{42} \mathrm{H}_{61} \mathrm{~F}_{6} \mathrm{FeN}_{4} \mathrm{P}_{3}$ 1994770

884.70

$0.405 \times 0.302 \times 0.219$

red prism

orthorhombic

$\mathrm{Pbc}$ a

110

18.324(6)

21.144(7)

$22.237(6)$

90

90

90

$8615(5)$

9104

$5.76,67.32$

8

3728

1.364

0.71073

0.523

Bruker Kappa Axis Apex2

$\varphi$ and $\omega$ scans

72.784

0.999

348006

20954

0.0566

20954 
Cut off Threshold Expression

Structure refined using

Weighting Scheme

Number of parameters in least-squares

$\mathrm{R}_{1}$

$\mathrm{wR}_{2}$

$\mathrm{R}_{1}$ (all data)

$\mathrm{wR}_{2}$ (all data)

GOF

Maximum shift/error

Min \& Max peak heights on final $\Delta \mathrm{F} \operatorname{Map}\left(e^{-} / \AA\right)$
$\mathrm{I}>2 \sigma(\mathrm{I})$

full matrix least-squares using $\mathrm{F}^{2}$

$\mathrm{w}=1 /\left[\sigma^{2}\left(\mathrm{Fo}^{2}\right)+(0.0440 \mathrm{P})^{2}+3.9205 \mathrm{P}\right]$ where $\mathrm{P}=\left(\mathrm{Fo}^{2}+2 \mathrm{Fc}^{2}\right) / 3$

512

0.0372

0.0886

0.0606

0.1005

1.006

0.002

$-0.452,0.642$

Where:

$\mathrm{R}_{1}=\Sigma\left(\left|\mathrm{F}_{\mathrm{o}}\right|-\left|\mathrm{F}_{\mathrm{c}}\right|\right) / \Sigma \mathrm{F}_{\mathrm{o}}$

$\mathrm{wR}_{2}=\left[\Sigma\left(w\left(\mathrm{~F}_{\mathrm{o}}^{2}-\mathrm{F}_{\mathrm{c}}^{2}\right)^{2}\right) / \Sigma\left(w \mathrm{~F}_{\mathrm{o}}^{4}\right)\right]^{1 / 2}$

$\mathrm{GOF}=\left[\Sigma\left(w\left(\mathrm{~F}_{\mathrm{o}}{ }^{2}-\mathrm{F}_{\mathrm{c}}{ }^{2}\right)^{2}\right) /(\text { No. of reflns. - No. of params. })\right]^{1 / 2}$

\section{References}

1. Stubbs, J. M.; Chapple, D. E.; Boyle, P. D.; Blacquiere, J. M., Catalyst Pendent-Base Effects on Cyclization of Alkynyl Amines. ChemCatChem 2018, 10 (17), 4001-4009.

2. G. Märk1, V.; Jin, G. Y.; Schoerner, C., 1.5-Diaza-3.7-diphospha-cyclooctane. Tetrahedron Lett. 1980, 21 (15), 1409-1412.

3. Fihri, A.; Luart, D.; Len, C.; Solhy, A.; Chevrin, C.; Polshettiwar, V., Suzuki-Miyaura cross-coupling coupling reactions with low catalyst loading: a green and sustainable protocol in pure water. Dalton Trans. 2011, 40 (13), 3116-3121.

4. Zhang, F.; Jia, J.; Dong, S.; Wang, W.; Tung, C.-H., Hydride Transfer from Iron(II) Hydride Compounds to NAD(P)+ Analogues. Organometallics 2016, 35 (8), 1151-1159.

5. Li, D. Y.; Shi, K. J.; Mao, X. F.; Zhao, Z. L.; Wu, X. Y.; Liu, P. N., Selective cyclization of alkynols and alkynylamines catalyzed by potassium tert-butoxide. Tetrahedron 2014, 70 (39), 7022-7031. 
6. Weber, K.; Weyhermüller, T.; Bill, E.; Erdem, Ö. F.; Lubitz, W., Design and Characterization of Phosphine Iron Hydrides: Toward Hydrogen-Producing Catalysts. Inorg. Chem. 2015, 54 (14), 6928-6937.

7. Varela-Fernández, A.; González-Rodríguez, C.; Varela, J. A.; Castedo, L.; Saá, C., Cycloisomerization of Aromatic Homo- and Bis-homopropargylic Alcohols via Catalytic Ru Vinylidenes: Formation of Benzofurans and Isochromenes. Org. Lett. 2009, 11 (22), 5350-5353.

8. Patiny, L.; Borel, A., ChemCalc: A Building Block for Tomorrow's Chemical Infrastructure. J. Chem. Inf. Model. 2013, 53 (5), 1223-1228.

9. Bruker-Nonius; SAINT; version; 2013.8, 2013, Bruker-Nonius, Madison, WI 53711, USA

10. Bruker-Nonius; SADABS; version; 2012.1, 2012, Bruker-Nonius, Madison, WI 53711, USA.

11. Sheldrick, G., SHELXT - Integrated space-group and crystal-structure determination. Acta Crystallogr. Sect. A 2015, A71 (1), 3-8.

12. Sheldrick, G., Crystal structure refinement with SHELXL. Acta Crystallogr. Sect. C 2015, $C 71(1), 3-8$.

13. Macrae, C. F.; Bruno, I. J.; Chisholm, J. A.; Edgington, P. R.; McCabe, P.; Pidcock, E.; Rodriguez-Monge, L.; Taylor, R.; van de Streek, J.; Wood, P. A., Mercury CSD 2.0 - new features for the visualization and investigation of crystal structures. J. Appl. Cryst. 2008, 41 (2), 466-470. 